\title{
THE CHANGING ROLES OF ARCHAEOLOGY IN SWEDISH MUSEUMS
}

\author{
Anders Högberg ${ }^{1} \&$ Fredrik Fahlander ${ }^{2}$ \\ ${ }^{1}$ Linnaeus University \\ School of Cultural Sciences, Archaeology \\ 39182 Kalmar, Sweden \\ anders.hogberg@Inu.se \\ ${ }^{1}$ University of Johannesburg \\ Centre for Anthropological Research, \\ Department of Anthropology and Development Studies \\ P.O. Box 524, Auckland Park, 2006, South Africa \\ ${ }^{2}$ Stockholm University \\ Department of Archaeology and Classical Studies \\ Lilla Frescativägen 7, 10405 Stockholm, Sweden \\ fredrik.fahlander@ark.su.se
}

\section{INTRODUCTION}

In recent years, the position of archaeology in Swedish museums has gone through a series of structural reorganizations. There have been many previous reforms over the years, but recent developments are more substantial, and in some cases even involve the closing of archaeological research, fieldwork, outreach, and education at regional and local museums.

Historically, archaeology and archaeologists have had a prominent role in Swedish national and regional museums of cultural history. In the nineteenth century, scholars and museum workers were busy with typological and chronological endeavours, supplementing and organiz- 
ing the collections. This early work by archaeologists and curators laid the foundation for both modern museums and archaeology as a scientific field (Nicklasson \& Petersson 20I2). This work gradually became more professionalized during the early twentieth century and the regional museums of cultural history were also reorganized in a nationwide system under the auspices of Historiska museet (The Swedish History Museum) and Nordiska museet (The Nordic Museum), both located in Stockholm. In the first half of the twentieth century, the number of regional museums increased and from the I930s onwards many were turned into Länsmuseum (Regional County Museums) with the specific task of caring for the heritage of each individual county (Bergström \& Edman 2005). These museums increasingly developed a professionalized regional management for heritage protection and conservation (Nilsson \& Rudebeck 20I0). Archaeological excavations and archaeological exhibitions were thus an essential part of these museums.

\section{POLICY CHANGES AND NEW ORGANIZATION}

The first publication of MUS 65, Kulturminnesvarrd (SOU 1972:45), represents a tipping point that changed the role of archaeology in the regional museums. The report introduced cultural heritage management as an explicit part of regional community planning. A new position as Länsantikvarie (Head Antiquarian) was established in each county, with the responsibility for new cultural heritage units at Länsstyrelsen (the County Administrative Board), working as the extended arm of the state at the county level (Pettersson 2003). This new organizational structure laid the foundation for the traditional distribution of roles between the County Administrative Boards (administration and control), the Regional County Museums (collecting and outreach) and the universities (research and education).

In the I990s, Riksantikvarieämbetet (the Swedish National Heritage Board) started to put pressure on Swedish contract archaeology ${ }^{\mathrm{I}}$ to develop, from a previous focus on excavation and documentation to now also include research as part of the contract archaeological endeavour. This was a response to the government bill Utbildning och forskning: Kvalitet och konkurrenskraft (Prop. 1993/94:I77), which declared that contract archaeology should be reconsidered as a research process. Contract archaeology units all over Sweden were now encouraged to

Contract archaeology is called uppdragsarkeologi in Swedish. In English it is sometimes also translated as 'development-led archaeology' or 'CRM archaeology'. 
formulate so-called 'scientific programmes' that specified the goals for their business (Johansen 1998; Högberg \& Rudebeck 200I). Although several actors in contract archaeology already had researchers employed and ran research projects (for example UV-Syd I999; Rudebeck et al. 200I), the development of the sector towards research strengthened the knowledge production in many regional museums. When analysis and research now became an explicit part of the museums' archaeological activity, more researchers were recruited. Also, employees were encouraged and given opportunities to take a doctoral degree. Many archaeologists at museums thus became quite well educated in relation to other museum staff (Nilsson \& Rudebeck 20I0).

In the mid I990s the government presented another bill, Uppdragsarkeologi m.m. (Prop. 1996/97:99), which suggested that contract archaeology should be deregulated, and work in a system of contract-based market competition. Since MUS65, contract archaeology had been a non-profit enterprise in which Länsstyrelsen had full control over costs, and also assigned contracts for excavations to local or regional archaeological actors. Hence, suggestions made in Uppdragsarkeologi m.m. implied wide-ranging changes in how contract archaeology in Sweden was to be organized. The implementation of the measures proposed in the bill took time. But, after some years of amendment, contract archaeology in Sweden is now subject to market competition.

In the government inquiry Uppdragsarkeologi itiden (SOU 2005:80) the purpose of contract archaeology was clearly formulated in relation to the goals of the national culture policy for the heritage sector. The proposal advocated that contract archaeology has broader purposes and responsibilities besides excavating, documenting and doing research. Consequently, in this bill it was suggested that contract archaeology to a higher degree than before should cooperate with the society outside archaeology. In this inquiry, Länsmuseerna are seen as natural collaboration partners for contract archaeology.

The broad ideas on cooperation with society expressed in Uppdragsarkeologi $i$ tiden were never fully realized, however. Instead, in the following bill Kulturmiljöns mångfald (Prop. 20I2/13:96), it was suggested that 'some outreach (förmedling) of the results of an archaeological excavation to the general public and society as a whole' should be included in excavation projects (Prop. 2012/13:96 Kulturmiljöns maingfald 2013:62). Today, Swedish contract archaeology follows this bill which comprises excavation, documentation, research, reporting to heritage bodies, and communicating the results to the general public. Another consequence of this bill is that Länsmuseerna no longer are considered as given partners for contract archaeology. This was criti- 
cized when the bill was circulated for comments. Länsmuseernas Samarbetsrad (the County Museum Cooperation Council), for instance, stressed that the possibility of linking contract archaeology to the county museums ought to have been examined more closely (Prop. 20I2/I3:96 Kulturmiliöns mångfald 2013:63).

\section{CONSEQUENCES}

The changes made to Swedish contract archaeology sketched above have fundamentally affected the conditions for archaeology and archaeologists at the regional museums. In a contract archaeology market that is now subject to competition, companies are expected to have a full transparent economy. Everything has to be financed by contracts. No work is allowed to be subsidized by grants. One consequence of this is that the majority of archaeological units at the museums have been separated from the rest of the museum organization, mainly in the form of in-house contract archaeological companies. This has been organized in different ways in different regions. Some archaeological companies maintain their relation to a regional museum by way of ownership structures. In other regions, contract archaeology has been detached from the museum. As an effect, former museum archaeologists have started archaeological companies with no formal link to a museum. Consequently, the museums have lost much of the archaeological research competence built up since the mid I99os.

The lost link to knowledge production based on archaeological research has in several cases led to a shortage of archaeological competence among the staff who administer archaeological collections. Equally, several contract archaeology companies have lost much of their relation to the museums and to the special competences the museums have. The traditional link between, on the one hand, archaeological fieldwork such as survey, excavation, documentation and research, and on the other hand, the archaeological work of regional museums, such as archive maintenance, collection management, working with exhibitions and public archaeology, has thus become weaker.

At the same time, several Länsstyrelser require that contract archaeology companies communicate their results of archaeological excavations in collaboration with county museums. In some cases, such cooperation between archaeologists and museum educators has led to outreach programmes that mediate new knowledge produced by the excavation project. In most cases, however, it tends to result in activities in which the archaeological excavation functions as a mere prop to mediate nar- 
ratives about the past that were already known before the excavation started (see discussion in Malmlöf 20I3). Broad cooperation with society outside archaeology, as envisaged in the bill Uppdragsarkeologi $i$ tiden, is not included in today's contract archaeology.

From the development outlined above it is apparent that the role of archaeology in regional contexts has changed substantially. For the first time since the regional museums of cultural history were established in Sweden, archaeology and archaeologists no longer have a given role in the regional museums.

At the same time, recent years have also involved other changes. The archaeological excavation activity formerly pursued by Riksantikvarieämbetet (Uppdragsverksambeten, $U V$ ), has since 2015 been transferred to Statens Historiska Museer (SHMM) in Stockholm. This means that Riksantikvarieämbetet has lost about a hundred archaeologists formerly employed at the authority, while Statens Historiska Museer have acquired roughly as many. Consequently, there has been a boost to an institution that traditionally has been strong in archaeological research and has always had archaeologists employed for research (Grundberg et al. 2015). At Riksantikvarieämbetet, which according to the government's new cultural heritage policy has been assigned the role as the consultative umbrella authority responsible for museum issues, much of its former contract archaeological competence has been lost.

Another change concerns the administration of museum collections. In the government cultural heritage bill, Kulturarvspolitik (Prop. 20I6/I7:II6), museums have been given extended mandate to manage processes of discarding artefacts in their collections (de-acquisition). This is seen as a necessary development by many museums, but also as a task difficult to handle in everyday practice (Sveriges museer n.d.). For museums with archaeological collections, however, such process of discarding artefacts can be especially difficult since many of them have lost much of their archaeological competence.

From what has been sketched above, we see a number of trends and changes concerning the role of archaeology in Swedish museums that may result in various predicted and unforeseen consequences. In this year's volume of Current Swedish Archaeology we have invited a number of Swedish archaeologists and researchers to give their views on this, and to discuss how they see the future roles of archaeology at Swedish museums: What are the consequences of the outlined trends and changes of the roles of archaeology at Swedish museums? What does the future for archaeology at Swedish museum look like? Are there new possibilities to be found in these developments? How can museum archaeology develop in the future? 


\section{REFERENCES}

Bergström, A. \& Edman, V. 2005. Folkhemmets museum: Byggnader och rum för kulturhistoriska samlingar. Stockholm: Byggförlaget.

Grundberg, M., Hegardt, J., Nordström, P. \& Svanberg, F. (Ed.) 2015. Ett museum måste irritera: Fyra röster om Historiska museet. The Swedish History Museum, Studies 24. Stockholm: Historiska museet.

Högberg, A. \& Rudebeck, E. 200I. Theory and Practice in CRM Archaeology: A Presentation of the Research Program for Malmö Heritage, Sweden. In: Bergstøl, J. (Ed.). Scandinavian Archaeological Practice - In Theory: Proceedings from the 6th Nordic TAG, Oslo 200I. Pp. 428-444. Oslo: University of Oslo.

Johansen, B. I998. Att utveckla och synliggöra uppdragsarkeologins resultat: Förslag till arkeologiskt stöd från Riksantikvarieämbetet. Unpublished.

Malmlöf, M. (Ed.). 20I3. Förmedlingens möjligheter: Några framtidsperspektiv på uppdragsarkeologi. Rapport 2013:5. Stockholm: Länsstyrelsen i Stockholms län.

Nicklasson, P. \& Petersson, B. (Eds). 20I 2. Att àterupptäcka det glömda: Aktuell forskning om forntidens förflutna i Norden. Acta Archaeologica Lundensia Series Prima in $4^{\circ}$, No. 32. Lund: Lund University.

Nilsson, B. \& Rudebeck, E. 2oıо. Arkeologiska världar. In: Nilsson, B. \& Rudebeck, E. (Eds). Arkeologiska och förhistoriska världar: Fält, erfarenheter och stenåldersplatser i sydvästra Skåne. Pp. I I-82. Malmöfynd I9. Malmö: Malmö Museer.

Pettersson, R. 2003. Den svenska kulturmiljövårdens värdegrunder: En idéhistorisk bakgrund och analys. Skrifter från forskningsprogrammet Landskapet som arena 7. Stockholm: Umeå University.

Rudebeck, E., Ödman, C., Samuelsson, B.-Å, \& Högberg, A. (Eds). 200I. Vetenskapligt program för Malmö Kulturmiljö: Den arkeologiska verksambeten. Malmö: Malmö Kulturmiljö.

UV-Syd 1999. Vetenskapligt program för UV-Syd I999-2002. Rapport UV-Syd I999:35. Lund: Riksantikvarieämbetet.

\section{Internet resource}

Sveriges Museer. (n.d.). Karlskrona: Sverige museer. [online] Available at: $<$ http://www. sverigesmuseer.se> [Accessed 30 November 20I7].

\section{Bills and proposals mentioned in the text, with translated titles}

Kulturarvspolitik (Heritage Policy). 20I7. Regeringens proposition 20I6/17:1 I6. Stockholm: Riksdagen. [online] Available at: <http://www.regeringen.se/4933fd/conten tassets/I27b80d33bo84I94a4I5d72b8572I874/I6I7II600web.pdf> [Accessed 30 November 2017].

Kulturmiliöns mångfald (The Diversity of the Cultural Environment). 2013. Regeringens proposition 20I2/I3:96. Stockholm: Regeringen. [online] Available at: <https:// data.riksdagen.se/fil/95 I97548-2 IB8-42BF-80B8-8C96BFA0572C> [Accessed 30 November 20I7].

Kulturminnesvård (Culture Heritage Management). I972. Statens offentliga utredningar I972:45. Stockholm: Liber. [online] Available at: <http://weburn.kb.se/metadata/477/SOU_7257477.htm> [Accessed 30 November 20I7]. 
MUS 65, I965 års musei- och utställningssakkunniga (The 1965 Museum and Exhibition Experts). [online] Available at: <http://weburn.kb.se/metadata/349/SOU_62I349. htm $>$ [Accessed 30 November 2017].

Uppdragsarkeologi itiden (Contract Archaeology for the Times). 2005. Statens offentliga utredningar 2005:80. Stockholm: Fritzes. [online] Available at: $<$ http://www.gov. se/49bb98/contentassets/4foe76792d98479eac694ffd 7 I 879534/uppdragsarkeologii-tiden> [Accessed 30 November 20I7].

Uppdragsarkeologi m.m. (Contract Archaeology etc.). 1997. Regeringens proposition I996/97:99. Stockholm: Regeringen. [online] Available at: <http://riksdagen.se/sv/ dokument-lagar/dokument/proposition/uppdragsarkeologi_GKo399/html> [Accessed 30 November 20I7].

Utbildning och forskning: kvalitet och konkurrenskraft (Education and Research: Quality and Competitiveness). I994. Regeringens proposition 1993/94:177. Stockholm: Regeringen. [online] Available at: <https:/www.riksdagen.se/sv/dokument-lagar/ dokument/proposition/utbildning-och-forskning_GHo3 I77> [Accessed 30 November 20I7]. 



\section{MORE THAN OBJECT HANDLING}

The Roles of Archaeologists within Museum

Organizations

\section{Gunnar Andersson}

The Swedish History Museum

Department of Cultural History and Collections

Box 5428, 11484 Stockholm, Sweden

gunnar.andersson@shm.se

The subject of the discussion is museums, and more specifically museum archaeology and the roles that archaeologists have - or should have within present as well as future museum organizations. It is a muchneeded discussion since one of the consequences of the changes that have occurred in Swedish contract archaeology during the last decade is that quite a few museums have dropped their archaeological functions. As stated in the introductory text by Högberg and Fahlander, there is an ongoing trend that many regional museums are cutting off their archaeological departments. But I guess it is fair to admit that the discussion to some degrees also can be related to the - sometimes - heated and lively debate about the roles of Swedish museums that has been going on during the last year in the press and social media; a debate which sometimes touches upon the question of whether there is any need for specialists, i.e. qualified academic researchers and curators, within the personnel group or not in the 'new' reorganized institution.

In the following I will try to elaborate and reflect on a few issues that to varying degrees have bearing upon some of the changes that have occurred - or might be about to occur - within Swedish contract archae- 
ology as well as within museums that either have archaeologists employed or have archaeological collections. It will be in no way near a complete overview and there are also great differences between museums. Some have vast archaeological collections, others have not. Some have archaeologists active in contract archaeology, but no collections, while others have collections, but no archaeologist working with contract archaeology. So as the situation appears today it is possible to have both, one or none of the above-mentioned branches in the organization. However, being fortunate in having spent many years working in both camps, I do believe I am qualified to comment on some the trends that I (we?) can foresee and express my own personnel view on. One of them is the above-mentioned undergoing change within many regional museums.

So even if all museums are not alike, one thing they have in common is that they undergo changes over time - and they need to do so; the opposite alternative is unthinkable, unnatural and unacceptable. However, it is my firm belief that in order to secure and maintain a high (or at least acceptable) standard and credibility, museums that do have archaeological collections also need to have archaeologists employed on a permanent basis.

It goes without saying that museum archaeologists do different work today than what they did Io, 20 or 30 years ago. Most of us probably don't do less, but more work than ever, often combined with struggling to fight cutting costs due to reduced grants for either ordinary museum work such as acquisition, i.e. registration and making materials available to the public online, having expert functions in exhibition productions or doing research. Tasks that requires the competence of a team of archaeologically skilled curators with different fields of expertise (the single curator/archaeologist capable of spanning the complete spectrum of archaeological material in a large museum collection that covers several millennia is yet to be born). Furthermore; through contacts with universities and different actors/companies, they need to be reasonably updated on what goes on, both within the academies and out in the different archaeological fields.

In many ways, however, we do different work today than earlier generations did: communication with visitors and public for instance. To a large degree this is done via direct e-mail correspondence between 'the expert' and the public. Communication of exhibitions is often done by skilled public educators - and they mostly do a fantastic job - but in many cases, it does also require archaeological competence. Another example of situations when this is needed is communication via the internet and social media. Many (most?) museums today communicate via blogs (administered by their own staff) and social media such as Face- 
book, Instagram, Twitter and Flikr, etc. When uploading materials from their collections (which has been a tremendous success and opportunity for museums to open up their collections) or other research results - museums meet and interact with more, and in many cases 'new' kinds of, visitors than ever. If these conversations are solely managed by staff working with PR or media who is skilled in their professions, but have limited or no archaeological knowledge, the information as well as the following conversation might be in need of serious revision.

For museums that have existing archaeological material from excavations, or have expressed a wish to receive this, it is of vital importance to have expert competence at hand. If meaningful channels of contact between excavators and museums exist, or can be established, this has the potential to facilitate object handling during fieldwork. The acquisition process can start earlier and the amounts of double work that often occur as a result of non-existent communication between the two may be reduced, if not to a minimum then at least considerably. Different economy systems between museums and archaeological companies should not be used as a hindrance to communication; if there is a will, there are ways to bypass such bureaucratic obstacles.

Updated archaeologists at museums also have possibilities to deepen and enhance the information connected to the objects and thereby increase the quality of the acquisition process, for instance, by adding contextual information which sometimes may not be included in files or lists submitted, but can be found in the reports, which are not always available on-line. Given the right incentive, acquisition work can sometimes be more than just object handling and described as a kind of post-excavation (and post-report) research process, for instance, by thematically structured approaches.

Another task in which archaeological competence should be required is when museums - if they follow the recommendations of ICOM (International Council of Museums) - specify their principles in policy documents concerning acquisition and de-acquisition of archaeological materials and objects. In both cases updated knowledge of current research and views has the potential to make these documents useful, for museum staff as well as for excavators.

Updated policies do not necessarily need to be primarily objectorientated, at least not in a simplistic way. A more fruitful approach to acquisitions could (or perhaps should?) - apart from emanating from what the museum wants its collection to mirror and represent - be context-orientated. The same goes for de-acquisitions. As an example: bulk material, i.e. materials and objects that a museum may have an abundance of in their collection, should of course be evaluated in rela- 
tion to the specific find context. It would be considered bad practice to let e.g. 'over-representation in the collections' be the only decisive criterion in the process.

Recently de-acquisition of archaeological materials, and the principles for it, has made its way into the general museum debate referred to earlier. In the debate the practice is often mentioned in negative terms and used as an example of the dismantling of good acceptable archaeological practice that is assumed to be currently going on in museums as well as among excavators, due to economic or political factors.

For several reasons I do not believe the answer is so simple. If a museum decides to get rid of its collections for economic or other politically motivated reasons, then the case is clear and in line with the arguments above. But if not, then it's something else. Among archaeologists there are those who are in favour and those who are not, and true - we can only speculate about what future development in archaeological theory and/or analysing techniques may result in - but in the end, I dare say that most archaeologists with insight into both museums and excavations - and excavation techniques - agree that in many cases deacquisition is a necessity. Naturally there are materials that for ethical reasons (hopefully) will never be considered, among them human remains. But again; context is the keyword and most archaeologists probably also agree that e.g. heavily corroded and fragmented objects that are beyond conservatorial salvation and identification, or objects without properly secured and documented context have less values than others.

When de-acquisition of objects such as the ones described above, for various reasons is needed, if conducted by archaeologist and in accordance with prevailing practices and policies, it should be regarded as an act of responsibility towards to those whom museums and excavators serve, now and in the future: the public, students, researchers, developers, decision makers at county administrative boards, their holders, etc.

It might also be wise to remember and acknowledge that de-acquisition is not a new phenomenon; it has a long history within museums. But the principles of it may never have been formalized in a policy. Furthermore, it has also been practised for long time within archaeological fieldwork and excavations - but in those contexts we generally name the process 'scientifically motivated priorities'. After all, it is in the field you decide, either as a group of researchers or as in contract archaeology in dialogue with the purchaser (i.e. the county administrative board), upon find strategies and what features or parts of the site are to be intensively or extensively excavated.

So to sum up: museums that have archaeological material in their collections are in need of archaeological expertise among the staff. To 
maintain - or (re?) establish fluent communication channels between those of us who are working in museums and those of us active in contract archaeology, is but one necessity for creating a better - and much needed - flow through the archaeological chain. If matters are evolving in an opposite direction towards where this is not considered necessary, then we really are on a slippery slope, and may soon find ourselves sliding downwards to full-scale deinstallation of good practice and fragmentation of knowledge. 



\section{THREE DECADES OF CULTURAL AND ECONOMICAL POLITICS, AND ITS EFFECTS ON ARCHAEOLOGY AT MUSEUMS}

\section{Mikael Eboskog}

Bohusläns museum

Box 403, 45119 Uddevalla, Sweden

mikael.eboskog@bohuslansmuseum.se

From a regional point of view that is based on the development of archaeological activities in the region of Bohuslän and Western Sweden during the last I5-20 years, I can note major changes for my museum, contract archaeological activities and the archaeological system. The changes that affect how contract archaeology is performed and how it is integrated into the museums operating in the region are not isolated phenomena that only touch on archaeology, but also convey to how the surrounding community relate to county museums and contract archaeology. County museums have long been struggling with decreasing budgets since public spending has been consistently lower than cost increases in recent decades, adding the new way of allocating appropriations through the portfolio model. This means that regional administrations (county councils, regions) allocate government and regional allocations to the entire cultural sector. The advantage that the funding comes closer to the receiving cultural institution through decentralization is offset by the fact that the appropriations, which cover less of the costs each year, cause internal competition between different cultural disciplines such as theatres, opera houses and museums for example. Another social development that has also affected the situation is the perception of museums. 
In the late I990s and early 2000 s museums were questioned politically and were most often seen as rigid, outdated colossi. Cultural politics was rarely spoken of, which is also reflected in the fact that most of the county museums were not mentioned in cultural programmes or the like; rather they were mentioned as a stakeholder among many others. Within regional boards, cultural amenities departments and politics, a need arose to change the museum landscape, preferably by incorporating the museums into regional administrations and dissolving the foundations representing the organizations of many county museums. Another contributing factor was that the county landscape had changed following discussions and the formation of large regions.

Another piece of the puzzle in understanding how and why contract archaeology has come to be an accessory to the main museum activities is the attitude toward public funds, private alternatives and competition. Society as a whole has moved towards increasing competition, increased privatization, outsourcing, which also led to the tightening of the procurement system (SFS 2007:I091 Lag om offentlig upphandling 2007, as an effect of Direktiv 2004/18/EG Om samordning av förfarandena vid offentlig upphandling av byggentreprenad, varor och tï̈nster 2004).

It is within this context where political ideas about reducing the major archaeological costs for infrastructure projects through competition combine with the museums' internal changes and increased need for cost-efficiency. It could be said that before competition emerged during the late 2000 s contract archaeology was the regulator museums needed to avert the difference between cost and allocation increases. When legislation and regulations opened up the market, it created two issues: a fear of losing income and an ideological problem.

The concern of lost income, or the understanding about this, differed between county museums depending on how exposed the museum was to competitors. One solution, for example, was to distinguish contract archaeology from other activities, partly to show that the business was not subsidized, partly not to confuse the county museums' building permit referrals with the contract assignments, but also to control the revenue against costs. Depending on where in the country, competition took a long time to emerge and when it did arrive museums were often poorly prepared. Museums were not organized as businesses, project or consultancy organizations and therefore found it difficult to quickly adapt to the new landscape. Meeting a market that operates in cycles requires that other organizations can profit in times of abundance and save for harder times. The effect on museums was dismantling in times of financial hardship, resulting in a lack of staff and skills when the business cycle turned upward, causing an inability to grow again. Further- 
more, there is the ideological difficulty of having a department that is competitive and profit-dependent within a public non-profit organization. When problems arose for contract archaeology, it was too often perceived by management boards as an economic risk, an outsider being a consultancy and extraneous to the museum's other activities. There was also an opinion that existed, and still exists, within the museum that competitiveness and revenue requirements excluded contract archaeology from other museum activities. Some museums then took drastic steps such s corporatization or closure.

Yet, it is not so that we who are active in contract archaeology at museums and who are both affected by and dependent on society and social change, passively awaited the inevitable. Many in the museum sector began to understand the problem of competition and the new so-called market quite early on. Initially, the focus was on the ability to compete and obtain assignments, by extension the financial condition for its existence. Cooperation with other museums became a way to meet the challenge and in 2008 the museum archaeology sector organization (M-ark) was founded. Early in this collaboration the need arose to connect contract archaeology and museum activities, and that question has been addressed with varying successes among the museums. And society has also begun to change its view of museums and archaeology. The loss of knowledge and relevance that comes with ending contract archaeology has influenced other museums in attempting to legitimize and strengthen their business. Politicians also speak more about museums and their role, which is increasingly relevant when contract archaeology needs to be communicated. The ill wind that affected the museum sector has, nevertheless, begun to change direction (see for example the new Prop. 20I6/I7:II6 Kulturarvspolitik 20I7) and has also brought with it a need to deliver more to society from the contract archaeological system.

The contract archaeological system that has emerged is in many ways one that is hastily unfinished and inconsistent regarding processes and market understanding. It simultaneously wants and does not want a competitive market. Policy does not allow free and direct procurement by developers, either at market-adjusted prices or with the certification of operators. The system, instead, allows Länsstyrelsen (County Administrative Board) to be the supervisory authority, the licensing authority, the contractor and the archaeological quality guarantor, all at the same time, but without giving the administrative board the necessary skills and resources to implement this. On the other hand, the system created a need for professionalism and long-term management of skills for the contract archaeology actors. In general, I would say that 
the archaeological quality has been significantly improved in terms of implementation since the system has been opened to competition. The same system, however, has most likely led us to excavate less and worse for the same cost. It may seem inconsistent to state that we have a higher quality of implementation while doing worse and less archaeology, but what I mean is that the archaeology that we do, we do better and more efficiently but we do not, or usually do not, have the chance to investigate as much. As a result, we risk investigating the archaeological site unsatisfactorily despite better techniques. Correspondingly contract archaeology loses social relevance when archaeological science and knowledge production suffer.

What that system is missing in practice is precisely archaeology's relevance and its need for knowledge development. With less archaeology conducted on a site we will sooner or later end up in the situation where we do not know whether we have gained new knowledge or not, whether we have understood the archaeological site now destroyed, or if we can guarantee the understanding of the cultural heritage for the future. The system also largely disregards who is responsible for the long-term knowledge building, either because it does not support Länsstyrelserna or they lack the ability, nor is it possible for individual actors who are dependent on project funding. In view of this, an excellent solution would be to ensure the role of museums in their mission as managing institutions to take care of and be responsible for this long-term knowledge building, a role largely expected of museums in any case. Unfortunately, the system excludes museums in everything except as archives and keepers of finds, disregarding the capabilities of the museums such as resources and economics. Nor do the authorities wish to perceive the museums as anything other than one of many actors in the contract system.

The fact that from a socio-economic perspective the system only benefits from the short-term economic cost of development and not the long-term loss of cultural heritage, heritage sites and cultural environments is exactly what is incompatible with today's market-adapted systems and the intentions of the legislation. Today's system fails with the wasteful mismanagement of museums as the guarantor of knowledge building, knowledge management and knowledge mediation. I would like the system process to be reviewed, with the aim of ensuring that the system first and foremost takes care of utilizing the knowledge from ancient sites that would otherwise be lost, to ensure knowledge production, that management structures for this knowledge are in place, and that the knowledge and results are accessible and promoted through mediation. 


\section{REFERENCE}

Kulturarvspolitik. 20I7. Regeringens proposition 20I6/I7:I I6. Stockholm: Riksdagen. Lag om offentlig upphandling. 2007. Svensk författningssamling 2007:I091. Stockholm: Finansdepartementet.

Om samordning av förfarandena vid offentlig upphandling av byggentreprenad, varor och tiänster. 2004. Europaparlamentets och rådets direktiv 2004/I8/EG. Europeiska unionen. 



\title{
AGENDA CULTURAL HERITAGE AND THE FUTURE OF ARCHAEOLOGY AT SWEDEN'S COUNTY MUSEUMS
}

\author{
Alexander Gill \\ Brännkyrkagatan 42, 11822 Stockholm, Sweden \\ alex.gill@bredband.net
}

Archaeology at Sweden's county museums is in trouble. An area of particular concern is the museums' responsibility for developing new areas of knowledge for management of the cultural environment. The museums' ability to participate in the development of management has not only been hurt by the deregulation of contract archaeology, but also by the way management itself began to be used as a political instrument at the onset of the new millennium, starting with the project Agenda Cultural Heritage ( $S w$. Agenda kulturarv).

In Sweden, management of the cultural environment is led by antiquarians employed by public authorities and museums. Antiquarians, usually trained as archaeologists or historians, are culture professionals who use judicial, economic and informative means of control to protect and preserve valuable historical buildings, remains, objects and environments. Antiquarian duties are important as they are connected to the creation of a historical consciousness in society.

In 1976 the organization of management was reformed. Länsmuseer (county museums), Länsstyrelser (County Administrative Boards) and Riksantikvarieämbetet (the National Heritage Board) were each handed distinct responsibilities that are still held today. The museums were given an earmarked grant from the state for developing knowledge about the 
cultural environment (Prop. 20I6/I7:II6 Kulturarvspolitik 20I7:I49). Since 20II the distribution of the grant has been determined at a regional level. With the exception of the county museum of Stockholm, the museums are handed their state funding in competition with the region's fine arts, libraries, archives, film production, arts and crafts, theatre, dance and music (SFS 20I0:201 2 Förordning om fördelning av vissa statsbidrag till regional kulturverksambet 2010; Prop. 2016/I7:I I6 Kulturarvspolitik 2007:I50). In 2009 the government acknowledged that Riksantikvarieämbetet was responsible for leading and coordinating knowledge-building initiatives (Prop. 2009/ıo:3 Tid för kultur 2009:74). According to heritage legislation the board is also responsible for supervising management of the cultural environment in the whole country (SFS I988:950 Kulturmiljölag I kap. 2 S). Länsstyrelserna have since 1976 been responsible for handling a majority of the legal issues connected to management.

\section{THE DEVELOPMENT OF CULTURAL ENVIRONMENT MANAGEMENT}

Through the years, management of the cultural environment has gradually developed. A few decades ago stewardship focused on the protection of monuments such as ancient remains, churches and certain buildings. The image of the past created by the protection of monuments was to a certain extent limited as it mainly appears to have been interested in establishing an awareness of a distant prehistory, Christianization and the state formation process. In the I980s entire environments began to be emphasized as the representation of history increased in complexity. The history of agriculture became a part of antiquarian undertakings as well as built-up environments connected to the history of urbanization (Prop. I987/88:104 Kulturmiljövaird I988:3I). At the turn of the new millennium the image of the past mediated by the antiquarian endeavour was elaborated again when remains of the history of industrialization began to be managed (Riksantikvarieämbetet 200I).

Lately, archaeologists in Sweden have shown a growing interest in the events of the Second World War and the Cold War (Burström et al. 2006; McWilliams 20I3; Axelsson \& Persson 20I6). Battlefield archaeology has been developed as well as garden archaeology (Knarrström 2004; Heimdahl 20I0). Antiquarians have also become interested in the preservation of 2oth-century architecture (Riksantikvarieämbetet 20I7). These examples demonstrate favourable conditions for developing antiquarian undertakings in the future, and thus for antiquarians 
to deliver even more complex understandings of history to the general public. For this to actually happen it is essential that county museums continue to employ archaeologists and heritage curators with the necessary resources to integrate scientific research and information into management of the cultural environment.

\section{THE MARKET}

Contract archaeology was deregulated in the late I990s and today there are numerous private and public enterprises on the market. However, the deregulation is not unique. Nowadays, knowledge about historical buildings, cultural landscapes, and other parts of the cultural environment has also begun to be sold to Länsstyrelser and other customers from a range of businesses. In fact a whole market for consultants has established itself within the area where county museums hold a responsibility for developing regional knowledge about the cultural environment.

The museums have adapted to the new circumstances in different ways. Some of them have sorted their business initiatives into separate organizations. Others have chosen to market their new services as a part of their regular operations. Several museums have claimed that being a part of the market is important for their ability to maintain competence and personnel within the field (Riksantikvarieämbetet 2015:7).

When Länsmuseerna adjust their operations to be competitive on the market they run a risk of neglecting their public duties connected to the development of knowledge. Some museums have also claimed that this is the case (Riksantikvarieämbetet 2015:32). Commercialization has created a situation where vast amounts of experience and knowledge, which was planned to be in the possession of county museums, is now in the charge of organizations that are not responsible for building knowledge to be used in the development of cultural environment management. The system created in 1976 has changed dramatically but a new system has yet to be put in its place.

\section{AGENDA CULTURAL HERITAGE}

The project Agenda Cultural Heritage was launched a couple of years after the deregulation of contract archaeology (Agenda kulturarv 2004a). The project's objective was to recast the antiquarian profession, from a line of work aspiring to solicit knowledge about the past into an activity carried out with the main purpose of being of use to society. Project docu- 
mentation reveals the ambition to shape the preservation and protection of the cultural environment into an instrument for fulfilling the societal needs of multiculturalism (Agenda kulturarv 2002b:4, 2004b:17, $2004 \mathrm{c}: 23)$. An intention was to increase public influence and participation over stewardship. History itself and its physical remains were to be discarded as the singular foundation of the antiquarian profession. Instead, present needs of society were to be honoured (Agenda kulturarv 2004a:6). One of the project's documents describes how participation could be increased at the nation's museums. Caretakers, museum guides, public relations managers, and carpenters should be heard before making decisions about what to protect and preserve (Agenda kulturarv 2002a:9). The established developmental process of gradually integrating new understandings of history into management of the cultural environment was thus to be given up in favour of a clearly anachronistic approach.

The redirection of stewardship that was initiated by Agenda Cultural Heritage over a decade ago is still evident. The strategy Vision för kulturmiljöarbetet 2030, recently launched by Riksantikvarieämbetet, is a clear example (Riksantikvarieämbetet 20I6). Lately, Riksantikvarieämbetet has also claimed that the regional redistribution of state funding to the arts and culture should not be earmarked for the employment of antiquarians at county museums. The argument put forward was that other areas of funding, such as arts and crafts, theatre, film production, etc. can also be construed as kinds of management of the cultural environment (2015/16:RFR4 Är samverkan modellen? 2015:95; Riksantikvarieämbetet $20 \mathrm{I} 7 \mathrm{~b}$ ). Riksantikvarieämbetets claim that areas of culture that are decidedly not responsible for transmitting history to the general public are on par with management of the cultural environment is astonishing. It means that professional actors, musicians, librarians, and others who do not have academic training in history are equated with antiquarians. Though difficult to agree with, the line of thinking at Riksantikvarieämbetet is comprehensible within the context of Agenda Cultural Heritage. Antiquarians with a scientific training in archaeology or history are not required for managing a cultural environment directed at fulfilling the present needs of society.

\section{THE FUTURE FOR ARCHAEOLOGY AT LÄNSMUSEERNA}

The system for integrating new forms of historical knowledge into management of the cultural environment created in 1976 has not only 
been damaged by commercialization. It has also been hurt by the ambition to develop the antiquarian profession into a tool for achieving objectives set by other areas of national policy.

The bill for heritage management presented by the Swedish government in 2017 concludes that the antiquarian profession has repeatedly been used by the state to serve different purposes. Through the years, management of historical remains has been used to glorify royal sovereignty and to construct the notion of a nation (Prop. 20I6/I7:II6 Kulturarvspolitik 2017:20-39). However, the government bill failed to recognize the instrumental use of history that has been an issue in Sweden since the onset of the new millennium.

The ambition of Agenda Cultural Heritage and Riksantikvarieämbetet of turning the antiquarian profession into a tool for serving the needs of society is at direct odds with the objectives of cultural policies originally set in Sweden in 1974. The government's policy for the arts and culture states that culture should be free and independent and not influenced or controlled by the objectives of other areas of national politics (Frenander 20I4).

To create a future for archaeology at Länsmuseerna it is necessary to recognize that the ideas championed by Agenda Cultural Heritage oppose the direction of cultural policy that Sweden's parliament has repeatedly confirmed. The ambition to de-professionalize the antiquarian line of work must be addressed. A necessary first step is the acknowledgment that management of the cultural environment needs to be controlled and developed by publicly employed antiquarians and that scientific knowledge about the past is a fundamental aspect of the antiquarian endeavour. After that the sector needs to begin solving the problems created by the ongoing process of commercialization.

\section{REFERENCES}

Agenda kulturarv. 2002a. Delrapport april 2002. Riksantikvarieämbetet dnr I08I327-2002.

Agenda kulturarv. 2002b. Projektplan. Riksantikvarieämbetet dnr 108-2098-2002.

Agenda kulturarv. 2004a. Människan i centrum: Agenda kulturarvs programförklaring. Stockholm: Riksantikvarieämbetet.

Agenda kulturarv. 2004b. Slutrapport Agenda kulturarv. Riksantikvarieämbetet dnr I08-874-2004. Stockholm: Riksantikvarieämbetet.

Agenda kulturarv. 2004 c. Utvärdering av arbetet med Agenda kulturarv regionalt och på Riksantikvarieämbetet. Riksantikvarieämbetet dnr 108-874-2004.

Axelsson, T. \& Persson, M. 20I6. Ledningsplats Björn och kalla krigets kulturarv. Gotarc Series C. Arkeologiska skrifter 79. Göteborg: Göteborgs universitet. 
Burström, M., Gustafsson, A. \& Karlsson, H. 2006. The Air Torpedo of Bäckebo: Local Incident and World History. Current Swedish Archaeology. Vol. I4. Pp. 7-24.

Frenander, A. 20I4. Kulturen som kulturpolitikens stora problem: Diskussionen om svensk kulturpolitik fram till 20Iо. Möklinta: Gidlund.

Förordning om fördelning av vissa statsbidrag till regional kulturverksambet. $20 \mathrm{IO}$. SFS 20I0:2012. Stockholm: Regeringen.

Heimdahl, J. 20I0. Barbariska trädgårdsmästare: Nya perspektiv på hortikulturen i Sverige fram till I200-talets slut. Fornvännen. Vol. I05. Pp. 265-280.

Knarrström, B. 2004. Hur gick det egentligen till när Skåne blev svenskt: Slagsfältsarkeologi kan kasta nytt ljus över historiska sanningar. Kulturmiljövård. 2004:2. Pp. 47-5I.

Kulturarvspolitik. 2017. Regeringens proposition 2016/I7:1 I6. Stockholm: Riksdagen.

Kulturmiliölag. SFS 1988:950. Stockholm: Kulturdepartementet.

Kulturmiliövård. I988. Regeringens proposition I987/88:I04. Stockholm: Regeringen.

McWilliams, A. 2013. An Archaeology of the Iron Curtain: Material and Metaphor. Diss. Stockholm: Stockholm University.

Riksantikvarieämbetet. 200I. Berättelser om vårt sambälles historia: Svenska industriminnen. Kunskapsavdelningen rapport 200I:5. Stockholm: Riksantikvarieämbetet.

Riksantikvarieämbetet. 20I5. Länsmuseernas och motsvarande museers kulturmiliöarbete: Kartläggning och redovisning av förutsättningarna för samverkan och verksambetsutveckling på regional nivå. Rapport från Riksantikvarieämbetet. Stockholm: Riksantikvarieämbetet.

Riksantikvarieämbetet. 20I6. Vision för kulturmiljöarbetet 2030: Redovisning av regeringsuppdrag om ett offensivt och angeläget kulturmiljöarbete. Stockholm: Riksantikvarieämbetet.

Riksantikvarieämbetet. 20I7a. The 6th Baltic Sea Region Cultural Heritage Forum: From Postwar to Postmodern - 2oth Century Built Cultural Heritage. Stockholm: Riksantikvarieämbetet.

Riksantikvarieämbetet. 20I7b. Yttrande. Kultursamverkan för ett Sverige som håller ihop: Framtida inriktning och utvecklingsmöjligheter för kultursamverkansmodellen. Ds 20I7:8. Riksantikvarieämbetet dnr. I243-20I7.

Tid för kultur. 2009. Regeringens proposition 2009/10:3. Stockholm: Regeringen.

Är samverkan modellen?: En uppföljning och utvärdering av kultursamverkansmodellen. 20I5. Rapporter från riksdagen 20I5/16:RFR4. Stockholm: Riksdagen. 


\section{THE GAP BETWEEN THE MUSEUMS AND CONTRACT ARCHAEOLOGY}

\section{Göran Gruber}

Stenbrötsgatan 10, 58247 Linköping, Sweden

goranfgruber@gmail.com

I am part of a research project, a pilot study, with the title FuTArk Funktionsvariation, Tillgänglighet, Uppdragsarkeologi (Dis-/ability, Accessibility, Contract Archaeology). The starting point for the project is that all people have the right to share in the past and participate in heritage processes on equal terms. In that context contract archaeology must be seen as a practice that ought to be available to everyone in the society. The question we ask is whether this actually is a reality. The project particularly focuses on the relation between contract archaeology and people with various disabilities. We know very little about this today even though our experiences indicate shortcomings when it comes to attitude, knowledge, as well as activities.

As part of the pilot study we conducted a survey during the spring of 20I7. It was aimed at members of Sveriges Uppdragsarkeologiska Branschorganisation (SUBo) and Museiarkeologiska branschorganisa- 
tionen (M-ark). ${ }^{\mathrm{I}}$ Our purpose was to get a quick overview of how the institutions within these associations handle questions concerning dis-/ ability and accessibility. I won't go through the results of the survey here. But in relation to the keynote discussion for this volume of CSA, it is interesting to see how museums within both these associations articulated their answers. They expressed themselves in three different ways (Engström 20I7):

- They described the way they handled dis-/ability issues on an overall level and in that context the contract archaeology functions within the museum were not visible at all.

- They described the way they handled dis-/ability questions on an overall level but with the addition that the answers were not relevant for the contract archaeological function within the museum.

- They only described how their contract archaeological function handled dis-/ability questions and made no relation to the general functions of the museum.

The way the museums answered this survey makes a split visible between the museum's general functions and their contract archaeological functions. This gap is not a novelty per se but a fact that is accentuated in the keynote discussion. There is a passage in the article that can be viewed as a way for us to understand this gap. It refers to the relation of contract archaeology to the goals of national culture policies and the goals of the cultural environment sector (kulturmiljövården) while also showing that there is a call from official authorities for a contract archaeology that 'has broader purposes and responsibilities besides excavating, documenting and doing research' (Högberg \& Fahlander, this volume)

This quotation reflects an important conceptual change within the cultural heritage sector, to extend goals beyond the 'self-formulated intra-sector' ones traditionally practiced. For a long time we have seen this change in the museum sector, although it is not as apparent in the

1 SUBo (Swedish Contract Archaeological Trade Association) 'is a trade association for organizations pursuing contract archaeology, including both public and private performers. The purpose is to act for fair and favourable terms nationally, and to make the social benefit of cultural environment work visible.' (Sveriges Uppdragsarkeologiska Branschorganisation n.d.). M-ark (Museum Archaeological Trade Association) is an association for regional and municipal museum archaeology. The purpose is 'to support members in their work with developing, building up and communicating archaeological knowledge which contributes to social relevance. In short, a socially healthy archaeology for everyone' (Museiarkeologiska branschorganisationen n.d.). The survey was sent to all members of both organizations, in total 26. Several museums are members of both organizations. 
practices of contract archaeology. In the long run this creates tension, with the result that the functions within the museums are slowly gliding apart from each other.

\section{GOALS, STRUCTURE, ECONOMY}

The goals for the regional museums have changed in recent decades. Formerly their main task was to collect artefacts and data concerning people's way of living in ancient/past times and display these artefacts, thus creating narratives about an imagined national (and/or regional) community. One example of this is the way the narrative of Swedish prehistory was articulated in the main exhibition of the National Historical Museum in Stockholm and how this notion got provincial replicas in different regional museums over the country. In recent years the goals of the museums have widened. Today regional, as well as national, museums are driven by multicultural and democratic perspectives (for example Sörmlands museum n.d.; Bohusläns museum n.d.). During the last few decades public communication (förmedling in Swedish), in the sense of one-way communication, has been problematized from a participation perspective. The same goes for the concept of cultural heritage, whether it is something we can point to or if it is created through our current use of the past.

In the local/regional rhetoric, museums are expected to provide perspective on the past as well as the present for a desired future. In that regard the museums are viewed as meaningful creative and cultural forces in place marketing when, say, churches, ruins of monasteries and castles related to the medieval past of the province of Östergötland, Sweden, are staged as sites for the tourist gaze (Gruber 20IO).

Contract archaeology, in contrast, is formulated as a national practice even if the antiquarian work is done in a local/regional context. In recent decades we have witnessed how the government has repeatedly searched for new arguments to legitimize a contract archaeology that relies on legislation where the developer is singled out as liable for the costs:

- During the I990s the government argued for a mission to widen the practice and include scientific research as part of the antiquarian work with excavations and documentation. In the internal rhetoric of today, contract archaeology is a recognized form of scientific research! Meanwhile it may be noted that the scientific interpretations rarely become part of the museums' exhibitions. 
- During the early 2000 s the focus was on turning contract archaeology into a competitive market. Among many things, this has had the result that publicly funded parts of the museums no longer can be a part of contract archaeology projects since this makes for an unequal market. One way of solving this has been to create tariffs for internal billing.

- During the 2oros the wider social values of contract archaeology have received some attention, which in turn has meant that the heritage act has been adjusted and nowadays also enables public events, or communication (förmedling)!

In the local/regional context it goes without saying that the museums should be a part of different networks (for example Jönköpings läns museum 20I5). The contract archaeological practice is a part of the same networks but unfortunately these interactions seldom have the opportunity to develop. Instead they are hampered since contract archaeology is locked within an idea that the practice is a tripartite system consisting of the developer, the decision-making authorities and the contractors (archaeologist). In this system the citizens are reduced to passive receivers of the results that the archaeologists create (Arnberg \& Gruber 20I4). The barriers towards the citizens are amplified further as a result of the successive professionalization that the sector has undergone due to the marketization. However, this does not seem to be a prioritized problem within the political rhetoric. The focus has rather been on creating a contract archaeology sector consisting of as many different contractors as possible. Today we see a wide range of contract archaeology institutions - corporations, foundations, cooperatives, museum units. Diversity has thereby been created within contract archaeology practice while the tripartite system has been maintained.

\section{CONCLUSION}

One could state that while the museums are in a local/regional political context and function through wide networks, the contract archaeologists who work within the museums are part of a professional management practice that is regulated by law. While the museums in general strive to live up to the diversity and participation goals of cultural policy, the practice in contract archaeology is wobbling around trying to figure out how to manage to be antiquarian, scientific, marketable and public. Within the museums this creates tension of an ideological, legal, structural and economic character. Despite this dilemma there are some museums that 
have chosen to doggedly continue working with contract archaeology and maintaining the archaeological competence in-house. Others have chosen to dispose of this museum function, or to lay off part of the staff. This has in turn led to more new, small contract archaeology companies. Further museums have tried to find new operation areas of activities and/or collaborations which include their contract archaeologists.

The changes we have seen in the museum field in combination with an increasingly complex contract archaeology raises questions as to whether there is a place for the latter in the museums of today. If not, will the baby be thrown out with the bathwater now that the Swedish Heritage Act emphasizes public communication as part of the contract archaeology practices?

\section{REFERENCES}

\section{Literature}

Arnberg, A. \& Gruber, G. 20I4. Participate in a broader sense? Thoughts on Swedish contract archaeology and approaches to the public in the light of the excavations in Motala 1999-2013. Current Swedish Archaeology. Vol. 22. Pp. I57-182.

Engström, E. 2017 (ms) FuTArk - Funktionsvariation, Tillgänglighet, Uppdragsarkeo$\log i$, report.

Gruber, G. 20Iо. Medeltider: Samtida mobiliseringsprocesser kring det förflutnas värden. Diss. Linköping: Linköpings universitet.

\section{Internet sources}

Bohusläns museum. n.d. Våra värderingar. Uddevalla: Bohusläns museum. [online] Availible at: <http://www.bohuslansmuseum.se/om-oss/vara-varderingar/> [Accessed 4 August 2017].

Jönköpings läns museum. 20I5. Verksamhetsplattform 20I5-20I8. Jönköping: Jönköpings läns museum. [online] Availible at: <http://www.jkpglm.se/box-ommuseetr/Om-museet/Verksamhetsplattform-20I5-20I8/> [Accessed 4 August 20I7].

Museiarkeologiska branschorganisationen (M-ark). n.d. Välkommen till Museiarkeologiska branschorganisationen! Halmstad: Museiarkeologiska branschorganisationen. [online] Availible at: <http://www.m-ark.se/> [Accessed ${ }_{4}$ August 20I7].

Sveriges Uppdragsarkeologiska Branschorganisation (SUBo). n.d. Kulturmiliö och kulturarv. Stockholm: Sveriges Uppdragsarkeologiska Branschorganisation. [online] Availible at: <http://uppdragsarkeologi.se/> [Accessed 4 August 20I7].

Sörmlands museum. n.d. Sörmlands museums vision. Nyköping: Sörmlands museum. [online] Availible at: <http://www.sormlandsmuseum.se/om-oss/vision-ochkannetecken/> [Accessed 4 August 20I7]. 



\section{A NEW COUNTY MUSEUM}

The Museums and Contract Archaeology

\section{Richard Grönwall}

\section{A CHANGED MUSEUM LANDSCAPE}

The deregulation of Swedish contract archaeology at the end of the I990s fundamentally changed the conditions for the work of the regional museums. Whereas archaeological assignments had formerly been an important part of the museums' general work on behalf of society, they have since been increasingly regarded as a separate side branch of their work. Contract archaeology, however, has continued to be important for many museums, not just for the development of knowledge but also for the possibility of financing broader competence than would otherwise have been possible. The development of contract archaeology towards a market that is admitted regulated by the state but is still subject to competition has simultaneously proven to be difficult to combine with the role of public representatives in heritage management. Is it the consultant who makes the statement, and whose interests do the museums actually represent? The relationship to Länsstyrelserna (the County Administrative Boards) has also changed since the deregulation, since a museum's contract activity is perceived as an obstacle to formal cooperation. The requirements for purchasing publicly financed 
heritage management measures have further increased the distance between the county administrative boards and the museums, for example, concerning the former traditional museum assignment of managing ancient monuments and setting up signs at historic sites, which in certain counties today is entrusted to private entrepreneurs to undertake, paid with public money in return for state funding.

During my years as an archaeologist and head of section at Stockholm County Museum, I have been able to follow development at close quarters. Perhaps it is only now, after nearly two decades of competitive contract archaeology, that I can reflect with some detachment on the development and its consequences for museum archaeology. Though it must be added that there are still regional differences in the potential of the museums to pursue contract archaeology in Sweden, and that my perspective is that of the metropolitan region. The greatest changes have probably taken place in Stockholm County, a region with a generally high volume of contracts per year and a large number of actors in the sector. However, a similar trend can be expected in other parts of the country over the years to come, as the market 'matures' and businesslike, competitive companies develop. The question that ought to be asked is therefore perhaps not how the regional museums will perform in the competition, but how they instead can adapt to fulfil the public assignment of communicating the cultural heritage to the citizens.

\section{GOOD AND BAD ARCHAEOLOGY}

There are no studies showing that publicly owned contract archaeology is any better in quality than privately owned contract archaeology, or vice versa. The issue of whether such functions should be publicly owned or privately run is rather a matter of ideology, not a question of good or bad archaeology. My stance is that it is the public supervision of the work of contract archaeology companies that must ensure that such work is performed in accordance with society's needs and demands not whether the tasks are carried out by public institutions or private companies. The fact that contract archaeology in Sweden is exempted from the Public Procurement Act probably means that there is more direct public control than in many other sectors. How well the system works in practice is of course another matter, but this will not be explored further here.

Let us instead consider the key question: Is regional museum archaeology endangered and becoming extinct? If the term regional museum 

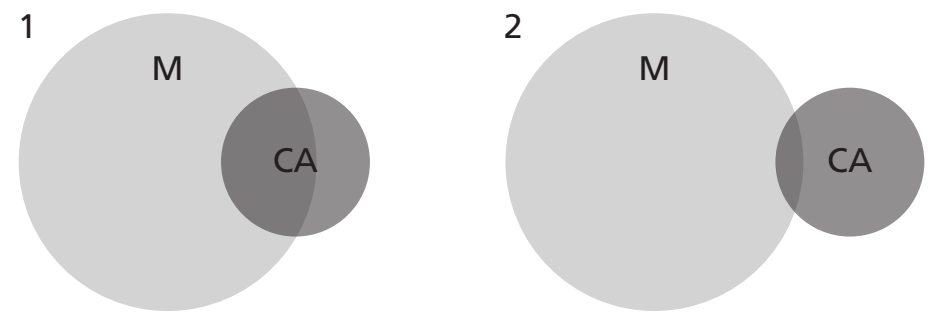

Figure I. The relative movement of contract archaeology (CA) from the museums (M) to other actors over time.

archaeology is to be understood as the archaeological activities traditionally pursued at the county museums, and based on its own work in contract archaeology, then the answer must undoubtedly be yes. This is not to say that this is necessarily negative for museum archaeology in a broader sense.

Figure $\mathrm{I}$ is a schematic illustration of how contract-financed archaeology has moved over time from the museums to other actors. The first stage reflects the situation before deregulation, when regional and municipal museums carried out many of the archaeological assignments, in 'competition' only with the excavation department of Riksantikvarieämbetet (the National Heritage Board). The second stage reflects today's situation, where a much smaller proportion of excavations is performed by the museums, while a growing share is now undertaken by private actors.

To a large extent, then, the regional museums have already lost the ground on which museum archaeology traditionally rested, and there is very little to suggest that this trend will be reversed. But why have the museums found it so difficult to compete with the private companies? To begin with, it may be noted that the total volume of archaeological contracts in Sweden is relatively small, with an annual turnover of only 300-500 million kronor on a national basis. ${ }^{\mathrm{I}}$ For most regional museums it is very difficult to keep up competitive excavation activity confined to one county. Looking for contracts outside the county could be envisaged as a conceivable solution on purely commercial grounds, but that would scarcely be in keeping with the purpose of a regional museum, and in many cases it would also mean competing with other regional museums that find themselves in the same situation. What then would need to happen if archaeology is not to disappear as a subject and a basis for knowledge development at the regional museums?

1 In the absence of national statistics, the figure is an estimate. 


\section{CLEARER ROLES - MORE ARCHAEOLOGY}

For many regional museums, work with the cultural heritage is closely associated with the practical work of heritage management pursued within their own region, which includes contract archaeology. The fact that a large share of the work today is done by actors who view the museums as competitors is of course a problem. When Länsstyrelserna also regard the museums as consultants on the same footing as private archaeological companies, the situation becomes even more problematic. The kind of mediation and communication that is linked to an individual excavation is part of the assignment today. One cannot expect, however, that more long-term goals and strategies for communicating and developing knowledge on the basis of the results of contract archaeology will be the main focus of private archaeological companies. That would require a different type of organization, competence and networks, which in turn requires long-term and expensive investments with a highly uncertain economic yield. For such work there are already established institutions - the public museums.

Instead there can be reason to aim for a clearer division of roles between the actors in order to develop contacts between private archaeological companies, regional museums and their target groups. For this to happen, however, it may be necessary for the museums to stop pursuing contract archaeology in competition with others, which may also seem inevitable today for purely economic reasons.

Figure 2 illustrates a conceivable future scenario with regional museums no longer pursuing contract archaeology. A new interface can then be developed for collaboration between museums and archaeological companies, where ongoing dialogue about the goals for knowledge development and communication can take place. A division of roles like this ought to bring new conditions for increasing the quality of methods and knowledge production in contract archaeology and also improving communication with the citizens. At the same time, the museums could

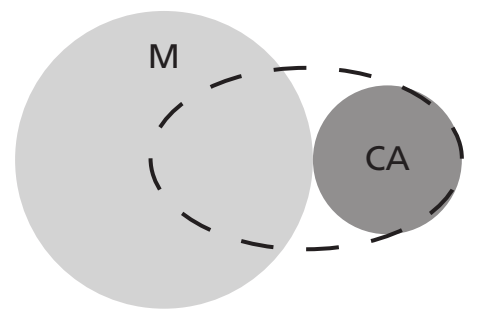

Figure 2. A suggested future relationship between museums $(\mathrm{M})$ and private actors working with contract archaeology (CA). 
resume closer formal cooperation with Länsstyrelserna, for example, in fields such as quality control and supervision of companies working in contract archaeology.

There is no doubt that we face immense challenges and that major changes are necessary. But I think it is exaggerated and pessimistic to believe that the museums will be forced to abandon the subject of archaeology as a consequence of the competition. In order to compete, the regional museums should instead develop a new and clearer role as institutions with the task of communicating the work of contract archaeology in collaboration with the companies that do it. Then there is a possibility that the museums will also attain the conditions needed for long-term knowledge development in cooperation with county administrative boards, universities and archaeological companies. 



\title{
ARCHAEOLOGY AND DEMOCRACY
}

\author{
Anders Hansson \\ Jamtli \\ Box 709, 83128 Östersund, Sweden \\ anders.hansson@jamtli.com
}

For me, museum archaeology is a question of democracy. Unfortunately, this good intention is not entirely compatible with the growth of commercial funding we find in archaeology today. The underlying concept behind Länsmuseer (county museums) and their archaeological expertise is that this expertise should be available to everyone wherever they live in the country. There are several reasons for this. Qualified archaeologists are needed to help private individuals with applications for building/planning permission on sites with ancient monuments or prehistoric remains; to answer questions on local history from the general public; and to help with lectures, talks, exhibitions etc. This expertise should be readily available across the entire country. The same is true for municipalities, regional boards and all types of associations that need professional advice. They also have the right to regionally-based expertise. This aspect of archaeological heritage is often provided by a nationwide network of qualified archaeologists whose positions are funded by government grants. However, there is also a need to provide archaeological expertise within limited time frames for investigations that go beyond this remit to encompass archaeological activity as stipulated by the Historic Environment Act. Länsmuseer that run commer- 
cially-funded archaeology units are often the ones that can take on such jobs at short notice.

At this point, I should make it clear that my point of departure is the situation in the northern half of Sweden. Here distances are great, there are numerous minor reports and investigations and large excavations are relatively few. This means that commercially-funded archaeology is a precarious economic commitment and the number of available archaeologists small. In order to manage such variation in archaeological activity, while retaining high professional standards, the limited resources available have to be utilized effectively and efficiently. This is one of the problems. To avoid contravening the rules of procurement in a competitive context there should be no overlap between the grantfunded and commercially-funded archaeological activities of a museum. Many museums have solved this problem within budgetary and administrative frameworks by creating separate units of commerciallyfunded archaeology with their own budgets; others have abandoned commercially-funded archaeological activities altogether. Demonstrating that commercially-funded archaeological activity is not subsidized by grant-funded activities ought not to be difficult, in theory. Demonstrating that grant funding does not contribute in any way to commerciallyfunded activities is almost impossible given the need for expertise of various sorts to evaluate and suggest plans of excavation and the need to pool various competences. This is certainly the case when the archaeologists at any given workplace are few in number.

These problems in the internal workings of museums have a parallel in the relationship between Länsstyrelser (County Administrative Boards) and museums. The report Uppdragsarkeologi $i$ tiden (SOU 2005:80) states that museums have 'an advantage over other investigative institutions since their status as consultative bodies has, already during the process initiated by Länsstyrelsen, brought them into close contact with the object of tender'. It also states that it is not 'suitable for Länsstyrelsen to approach a county museum or its equivalent for advice etc., when the matter is one in which the commercial unit at the museum can be one of the bodies competing for the tender' (SOU 2005:80 Uppdragsarkeologi $i$ tiden 2005:I43). Should the expressed intent of the legislation be followed slavishly, then, the combined qualifications and knowledge of the prehistory of a particular area available for a particular project will not be utilized. This in turn can lead to an impoverishment of the archaeological services provided, which would not be beneficial to the aims and needs of any party. Expressed more succinctly, the archaeological qualifications and knowledge associated with the museums become, in themselves, a problem. 
In recent years, the long-term aims of cultural heritage have been more difficult to achieve within the framework of commercially-funded archaeological activities at museums. What I am referring to is the aim that as many people as possible should participate in and be included in the work of cultural heritage. To achieve this requires a long-term initiative in which museums have a clear advantage. The trust and continuity required for the plausible achievement of these aims are generated by the museums being in situ, having knowledge of the region and with the opportunities to establish long-term contacts with the local population. This particular aspect of wider participation is less well achieved within the current arrangements for commercially-funded archaeology. Since such a large proportion of archaeological activity that takes place today is carried out on a commercial basis, what the general public may find interesting and exciting has to be determined by profitability. It has been demonstrated that the demands for a high level of scholarly expertise in conjunction with competitive efficiency is difficult to combine with the aims of long-term inclusivity. In a competitive structure with many small commissions, this is clearly the case. Should a large volume of archaeological activity in a region be run on a commercial basis then, unfortunately, we cannot provide access to archaeology in the manner we are required to do.

There is no doubt that much of the commercially-funded archaeology that is carried out today is better than it was thirty years ago. Stricter regulations and competition have undoubtedly contributed to this. Nor is there any doubt that more people have access to the results. Participation and inclusiveness, if by this we mean that ordinary people are actually involved in creating archaeology and, thereby, also contributing to the writing of history, appears much more problematic. That expertise in the region can be seen as an undesirable competitive advantage is equally problematic. It is here that I identify the major problem for achieving the ideals of museum archaeology. Good museum archaeology presupposes smooth cooperation between grant-funded and commercially-funded archaeological activities. But if we are to abide by current legislation and directives, it is just this that is put in doubt. We find ourselves in a paradoxical position in which the aims and guidelines for actively preserving cultural heritage are counteracted by cultural heritage legislation. With demands for greater professionalism and corporate organization, the museums face a new reality. The worst-case scenario is that commerciallyfunded archaeology will be separated completely from the museums. A museum archaeology that meets the aims of cultural heritage policies requires fieldwork, research and cooperation between grant-funded and commercially-funded activities. It is difficult to see an alternative. 
I recognize that Sweden is a geographically long country and that economic resources, projects and the numbers of archaeologists are unevenly distributed. Some of the problems I see from my northern Swedish window are probably not relevant to other parts of the country. But this is where democracy or a democratic perspective is so vital, in order to counteract this inequality.

\section{REFERENCE}

Uppdragsarkeologi i tiden. 2005. Statens offentliga utredningar 2005:80. Stockholm: Fritzes. 


\title{
UNLOCKING THE POTENTIAL OF COLLECTIONS AND ARCHAEOLOGY
}

\author{
Åsa M. Larsson \\ Swedish National Heritage Board \\ Box 5405, 11484 Stockholm, Sweden \\ asa.larsson@raa.se
}

The invitation to this special keynote discussion of Current Swedish Archaeology posed a number of questions for us to discuss or expand on. I will take the opportunity to focus on the developments I feel are necessary for archaeology and museums to take to be more than the crypt keepers of prehistory, or worse - irrelevant.

Museums and archaeology is certainly a relationship that has undergone some profound and challenging changes in Sweden over the past few decades. Partly from political changes making archaeology open to private competition, partly from the development of digital methods of documentation and dissemination. Turning information digital has afforded us opportunities that could barely be imagined by most archaeologist in the early I990s.

Theoretically we can now compare and analyse vast amounts of data in a very short time. In reality we can barely compare information from one excavation with another without substantial effort and are in fact in danger of losing much of the documentation for the future. 'Digitize the heritage' is now the rallying cry from both politicians and museums, but making something digital will not automatically make the information usable or even available. Instead, it can actually make the information less accessible. 
Digital heritage information certainly has the potential to be massively useful in ways we have only begun to realize. However, if that potential is to become reality then there are important steps that need to be taken by archaeologists and museums.

\section{THE POTENTIAL OF COLLECTIONS}

Museums are tasked with preserving collections for future generations because human experience cannot be adequately distilled into words on a page. Nor do we know everything that has happened, and these objects can help us to expand our knowledge through additional research.

It would be hubristic to say that we have retrieved as much knowledge as we possibly can from an object, as methods of research change and improve over time. At the most we may say that the cost of preserving certain objects outweighs the perceived benefits of any further knowledge to be gained from them, and that it can be replaced by documentation in some form. Most people, whether experts or laypersons, dispute neither the need for some preservation, nor the need for prioritizing what is to be added to a collection. We differ in degree rather than in kind.

Collections of course have more purposes than being research material - they are meant to be used for display and dissemination of knowledge to the public. However, most museums have collections that vastly exceed in quantity what could be exhibited in a meaningful way in a lifetime. It therefore feels as if the collections are sometimes viewed as elderly relatives that everyone agrees should be taken care of out of a sense of love and duty ('we wouldn't be here if it weren't for them, and they do make themselves useful now and then'), but who are viewed as not really pulling their weight anymore.

So can collections be made to pull their own - considerable - weight? Without a doubt, but only if we stop paying lip service to lofty ideals about collections as knowledge repositories, and start to enable them to work in that way.

We need to:

I. Unlock the full potential of collections as data.

2. Incorporate new research results into museum dissemination in a better way.

3. Have greater confidence in the public interest in history and prehistory. 
These points are interconnected. We are not working enough with developing the quality of digital data from collections and excavations, because researchers are treated as a small special-interest group, rather than as an indispensable asset for museums in public engagement and dissemination. As contract archaeology now operates as a business, archaeologists at museums are kept somewhat at a distance from the other parts of the organization. At the same time, museums with their own archaeological units are perhaps wary about opening up all their information to their potential competitors. However, this sort of thinking, where collections become a museum's private capital, will only hurt us all in the end.

Access to digital collection information cannot be restricted to privileged insiders. By restricting availability to the full content of the collection database, researchers are forced to waste time and money working as if they were still analogue. A physical object can only be housed in a single location, but digital collections are under no such limitation. Museums need to rethink the role of their collections: information need not be, should not be, restricted in this manner. Researchers are doing the essential work to generate new knowledge that ensures that both collections and new excavations are valued by society.

Museums should never ask Why something should be made available online, but rather ask Why not? If the objection is a sense of ownership then the museum is not living up to its fundamental duty towards the public in any meaningful way. More commonly the objection is lack of know-how and resources (budget as well as staff), and we have to work together to find ways to overcome that. Making collections available and usable is surely the best way to ensure that they as well as the curators will continue to receive funding. We are dangerously naïve if we think the people holding the purse strings are not prepared to pull the plug on 'useless' collections taking up space and resources. After all, if the purpose of a museum is only its exhibits, why even have a collection of stuff that will never be shown? If everything that can be learnt about an excavated site is presented in the report, then why keep anything afterwards?

\section{ARCHAEOLOGISTS NEED TO STEP UP}

I have spent a lot of time exhorting museums to rethink their collections so that they make better use of the digital potentials. However, I will not let archaeologists off the hook. What responsibility do we take, as members of a profession, to live up to the goals of documenting an excavation in a manner that is usable for others to critically examine and 
re-interpret? What responsibility do we take to work together to make sure we are using common semantics when possible, so that data can be compared and analysed?

It is remarkable how poor we have been at making sure we use the same terminology in even very basic documentation, which could ensure computer-based analyses and statistics without extensive re-digitization. We are focusing so much effort on using digital tools during excavations that we rarely stop to ask how to make sure product will be usable in another context. We still mostly think in an analogue manner, leaving vital information out which would ensure that data can be related to each other.

Yes, there should be better infrastructures in place to make sure archiving and dissemination of digital information is ensured, and some of it is in progress at Riksantikvarieämbetet (the National Heritage Board). But I strongly believe professionals need to take an active part in making sure archaeology develops standards that do the most good, and the least harm. Museum archaeologists should be in a better position than most others to work with these issues, both because they can collaborate across many museums ensuring multiple viewpoints, and because they can collaborate with the collection curators.

\section{RETHINK DISSEMINATION}

Finally, we must rethink what we mean by dissemination, finding ways to share knowledge. We must make sure that the information we collect in the field, the information we store at museums, and the information being created through research, are not wholly different products with little or no connection between them.

Yes, the situation has become quite challenging: archaeologists being in competition with each other, the growing wedge between field archaeologists and university researchers, and the financial difficulties of many museums. These are reasons for our current problems, but they are not excuses. We can and should create forums for dealing with common issues, and we can do a lot more to make sure we are actually delivering on our promises.

Archaeologists must learn how to create digital information in a manner that better ensures its re-usability. Museums need to make it easier for everyone to engage with their collections in order to unlock their massive potential. We all need to make a much better effort to make sure information is preserved and made available, so that future excavations are made from a position of improved knowledge. 
We need to put more effort into developing best practices and methods ensuring that heritage data can be used to create new knowledge and insight into the past, and through this a better understanding of our present.

I will end with some hopeful suggestions for archaeology and museums:

- Collaborate to develop 'best practices' for documenting digital information.

- Make use of good principles when creating and sharing data: i.e. persistent identifiers and Linked Open Data.

- Make digital collection data at museums open and free to use. 



\title{
CONTRADICTORY POLICIES The Museum Law in Regard to the Regulations for Contract Archaeology
}

\author{
Björn Magnusson Staaf
}

Lunds universitet

Institutionen för Kulturvetenskaper

Box 192, 22100 Lund, Sweden

bjorn.magnusson_staaf@kultur.lu.se

In 2017 a museum law was introduced in Sweden, the first of its kind in a Swedish context. The law says in its 8 th section that museum professionals must have an adequate competence and an advanced knowledge about the topics related to the subject field of the various museums. Section 8 also says that public museums shall contribute to research and the advancement of knowledge. This might appear as something selfevident, but the content of many laws is often seemingly obvious yet is still quite necessary to state. Developments that have taken place at Swedish museums during the last decade have also resulted in a drain of competence and expertise. This decline has of course also had consequences for the research and advancement of knowledge at museums, as well as for the quality of the pedagogical work. This decline of competence is particularly clear when it comes to the field of archaeology. It is my personal belief that the current museum law is a step in a new and better direction. Still, there are other legal regulations that more or less counteract the intentions of the new museum law, structures that to a large degree have caused a drain of archaeological competence at museums. 
Most visitors to museums still find archaeological collections and exhibitions interesting, and those who manage museums have nothing against archaeology. It is thus not a planned strategy on the part of the leaderships or boards of museums that has caused a drain of archaeological competence at many museums in Sweden. The most important reason for the current weak position of archaeology at Swedish museums is connected to developments within the field of contract archaeology that have taken place during the last two decades. Twenty years ago contract archaeology had a strong position at many Swedish museums. This is not the case any more.

Sometimes one can sense a touch of bitterness when talking to archaeologists working within the field of contract archaeology today. If one looks at how the conditions for contract archaeology have developed during the last fifteen years, this feeling is quite understandable. The academic quality of contract archaeology was once disputed. During the I990s the quality of research improved considerably, and became of a very high standard. The understanding of both prehistory and the medieval period has also radically transformed during the last decades thanks to the high scholarly ambitions in contract archaeology. However, this was not the only point of critique aimed at contract archaeology in the I990s. It was also questioned whether a wider audience, outside the circle of scholars, benefited from contract archaeology. Again, contract archaeology tried to answer these demands, and it has in a large number of cases also succeeded very well in doing so. There is today an impressive amount of quite extraordinary pedagogical projects that have been carried out within the framework of contract archaeology. The vast majority of these projects must be labelled as successful, from point of view of reaching new and heterogeneous audiences, developing new pedagogical methods, and achieving good results in conveying advanced and complex understandings of the past. Several of these projects were conducted within the frames of contract archaeology directly connected to museums. Yet, with a few exceptions it is very hard to find examples where these successful pedagogical projects have transformed museum practices on a more profound level. A reason for this is quite simply that the contract archaeology units at several museums have experienced redundancies, or have been shut down completely. The contract archaeology unit at Malmö Museums, for example, was one of the largest in the country twenty years ago. Today there is no contract archaeology unit at Malmö Museums, which still is one of the biggest regional museums in Sweden. The reason for this is that it has become more economically rational from a commercial point of view to conduct contract archaeology within organizations separate from museums. 
Contract archaeology in Sweden was a highly regulated practice until the late I990s. Each contract archaeology unit had its 'territory' for documentation and research. One can say that this system was closely connected to the national organization of regional museums that was introduced during the I970s in Sweden. During the late I990s these structures started to change. The primary reasons for this were two: one was that some building entrepreneurs found the cost of contract archaeology too high, another can be considered to be ideological. The ideals of New Public Management and New Liberalism had a breakthrough in politics and in public service in the I980s and I990s in Sweden. The general idea was that deregulation and a market-based economy would improve the quality of social services, increase efficiency and make it less costly. The implementation of New Public Management in Sweden has led to enhancements in several sectors of the public sphere, but not in all. It is highly debateable whether contract archaeology has had any real benefits at all from these structural changes.

One could argue that the quality of contract archaeology has become better with respect to the scholarly and pedagogical aspects, due to the changes in regulation. However, on a closer look it is clear that methodological and theoretical ambitions started to rise well before the structural transformations came about, for example with the excavations at Fosie that were directed by Nils Björhem and Ulf Säfvestad at Malmö Museums. It is also questionable whether the costs of the contract archaeology have become cheaper for the building entrepreneurs, which was the primary object of the deregulation. Seen from a wider perspective it might actually be that the cost efficiency of contract archaeology from a public social perspective has dwindled considerably instead. The cost of contract archaeology is still there, but the infrastructure for reaching a wider audience has become unstable. The development at the museums is a clear indicator of this.

The contract archaeology at museums was and is a fully self-financing undertaking. In other words, in the budgets of many museums archaeology is financed through other means than public funding, which normally is the most important source of income for Swedish museums. The old system where the contract archaeology units had their 'territories' gave a more stable ground for planning. Naturally, contract archaeology was sensitive to changes in economic cycles and shifts in building activities also in this system, but it guaranteed at least a form of continuity. It also ensured a presence of archaeological competence at the museums. The museum archaeologists were from this point self-financed, long before the ideas of New Public Management. The deregulation of contract archaeology disrupted the structures that had secured the pres- 
ence of archaeological competence at museums. It became more financially risky for museums to support contract archaeology when there no longer were any 'territories'. The risks of making an economic loss if the contract archaeology units didn't win the competitive bids for excavations became apparent. This was the reason to why the public culture management of the City of Malmö decided to shut down the contract archaeology at the Museums of Malmö. The partial deregulation of contract archaeology contributed to a lowering of the self-financing potential of museums.

The losses of income from contract archaeology which the museums suffered were not compensated by, for example, increases in public funding. The tougher conditions for contract archaeology at museums thus led in several cases to major redundancies in the archaeological staff in the 2000 s. It is the current structures of contract archaeology that are the primary cause of the drain of archaeological competence at least from the regional museums. It is not the alleged politicizing of museum practice that is sometimes claimed. These structures can partly be seen as obstructive to the ambitions of the new museum law and its practical implication, at least when it comes to the field of archaeological practice at museum. It is also a system that counteracts the intentions of the Culture Bill presented to the Swedish parliament in 2009. One of the aims presented in this bill is that the public cultural institutions of Sweden should strive for an increased level of self-financing.

It is now time, twenty years after the changes of regulation for contract archaeology, to make a thorough evaluation of what consequences they have had. It is of pivotal importance in this context to strengthen the archaeological competence at the Swedish museums, and to create new structures for pedagogical practices and research that guarantee continuity. It might seem very difficult and challenging once again to reform the regulations for contract archaeology. However, the system managed to change twenty years ago, therefore it must be possible to transform it again. Nor does it mean that a return to the conditions before the I990s is wanted. Yet, when looking at costs, it must be remembered that contract archaeology is not something that is done in the interest of the building entrepreneurs or real estate developers, it is done in the interest of the citizens. What is needed first and foremost is therefore a pragmatic public governance strategy with an aim of giving the citizens the best archaeological value possible in balance with reasonable financial costs. I am convinced that the museums have an important role to play in the development of such strategies. 


\section{IS COLLABORATION THE FUTURE FOR MUSEUM ARCHAEOLOGY?}

\section{Mikael Nordström}

Jönköpings läns museum

Box 2133, 55002 Jönköping, Sweden

mikael.nordstrom@jkpglm.se

\section{BACKGROUND}

What is museum archaeology? The simple answer is archaeology performed by archaeologists engaged at a museum, that is, everything from leading and implementing excavations (mainly in the form of contract archaeology) to taking care of artefacts or making the archaeological results public. What should be expected from a museum archaeologist? The person ought to have knowledge about the archaeological collections at the museum and have a good hunch about the regional cultural heritage and ancient monuments. Why do we perform museum archaeology? The answer lies most likely in the old museum slogan to 'collect, preserve and exhibit' the cultural heritage. This was more or less the reason for creating local heritage societies and museums at the end of the Igth century and the beginning of the 20 th century.

To facilitate the government in its work of guarding and protecting the nationwide cultural heritage, the demand for local presence arose, which resulted in county representatives for Riksantikvarieämbetet (the National Heritage Board). The representative was also head of Länsmuseet (the county museum). 
Länsmuseer have had the responsibility for regional cultural heritage matters since the I930s. A breaking point took place in 1976 when that role was transferred from the museums to Länsstyrelsen (the County Administrative Board). At the beginning of 2 Ist century a more profound change was launched when full competition and a multiplicity of companies was favoured over the importance of regional knowledge usually held within the museums.

The role of Länsstyrelsen presupposes of course a knowledge about the cultural heritage, but their knowledge about museum collections varies to a great deal.

The question is what role does museum archaeology play? Where do the Länsmuseerna fit in this new assignment?

\section{THE CHALLENGE}

The former special position of Länsmuseerna in working with the regional cultural heritage has eroded and within contract archaeology completely disappeared. The system for contract archaeology no longer makes exceptions for county museums with the justification that their unique knowledge of the regional cultural heritage should be appreciated, as was the case earlier (for instance SOU 2005:80 Uppdragsarkeologi i tiden 2005:80). Länsstyrelsen is obliged to see that there is a multiply of archaeological companies, and to purchase all excavations with a cost of more than 20 price base amounts (KRFS 20I5:I Riksantikvarieämbetets föreskrifter och allmänna råd om uppdragsarkeologi 2015).

The big losers in a system like this are companies who are restricted to work within a limited area, which means, above all, Länsmuseerna. Not only do they lose market shares, one must also be aware that contract archaeology, from time to time, has produced a considerable economic contribution the museums, which the museums to some extent have made themselves dependent upon for the maintenance of nonarchaeological activities (Länsmuseernas och motsvarande museers kulturmiljöarbete 2015:32ff.).

In times of economic decline this dependency could have serious consequences for the whole of the museum, not only the part dealing with contract archaeology. The county museums have great economic challenges (Länsmuseernas situation: En konsultrapport 20I6).

Is the solution to dismantle contract archaeology at Länsmuseerna to minimize the economic risk? Or to try to uphold the business as long as possible, slowly but surely losing competence and financial means? 
Contract archaeology at regional museums will be ousted if there isn't a very good and continuous market with limited competition.

The loss of competence because of reduced financial means at Länsmuseerna is not a problem confined to Sweden. That issue was discussed in November 2016 at Museums Association Conference and Exhibition in Glasgow (Glasgow Conference Guide 7-9 November 2016). A speech by a member of The Society for Museum Archaeology in a session titled 'Subject specialist networks: what next?' showed that less than half of the British museums 'with archaeological collections employ a curator with specialist archaeological expertise' (quotation from a Powerpoint presentation; see also Boyle et al. 20I6).

\section{CONSEQUENCES}

But even if Länsmuseerna no longer are an obvious performer and partner within contract archaeology, their mission in the work with the regional cultural heritage still remains (Prop. 2012/13:96 Kulturmiliöns maingfald 2013:63; see also Länsmuseernas och motsvarande museers kulturmiliöarbete 2015): 'The County Administrative Board shall, within the framework of its responsibility for cultural environmental work in the county, cooperate with the cultural environment authorities in the county, especially the county museums and corresponding museums' (SFS I988:I 88 Kulturmiljöförordning, Allmänna bestämmelser $\$ 2$ ).

That is also something that is highlighted in the government culture budget for 2018 (Prop. 20I7/I8:I Budgetpropositionen för 2018 20I8:I20). The government's bill states emphatically that the government grants which are distributed through the county councils also include the museums' work with cultural heritage (Prop. 2016/I7:I I6 Kulturarvspolitik 20I7:I48). The problem is that reduced public financing forces the museums to choose between disciplines such as ethnology, art, museum education, cultural heritage and archaeology. The public grants are not being increased enough to match the costs.

The author of this article is at present discussing next year's budget where resources for cultural heritage and archaeology have to stand back in favour of other investments and activities. In 2018 we will be down to the lowest level for the past 25-30 years regarding means for publicly financed museum archaeology. An obvious risk is that Länsmuseerna also are forced to refuse to store archaeological finds, because the expertise and resources to handle them is missing. This is a current issue at several museums today and also a question of great importance to Länsmuseet in Jönköping. 
Several museums have decided not to take part in the contract archaeology market, partly with the argument that publicly financed museums should not compete with private companies, partly because the economic risk is too high. Decreasing market shares in contract archaeology give an uncertain economic basis which causes Länsmuseerna to consider dismantling contract archaeology (Westerberg 2017:26; Ökad konkurrens på det uppdragsarkeologiska området: Vissa ändringar $i$ kulturminneslagen 2011:46f.).

\section{POSSIBILITIES}

If contract archaeology within the framework of Länsmuseerna is to survive, contract archaeology must have the opportunity to act outside the county borders in order to handle fluctuations in the market as well as to keep the necessary archaeological expertise - preferably through collaboration with other museums. This collaboration must be formalized in some way. How to accomplish this is the big question. In the worst case the old understanding that regional museums do not compete with each other has to be abandoned.

Within Museiarkeologiska branschorganisationen M-ark (The Museum Archaeological Trade Association) forms for collaboration between contract archaeologists at different Länsmuseer have developed. This has been absolutely necessary for the museums to be competitive in a tendering procedure.

The progress of publicly financed archaeology is even more uncertain because archaeology is only one of several disciplines that the museums are expected to maintain. What should be the priorities in times of reduced grants? An important future issue for Länsmuseerna will therefore be to discuss forms for collaboration. We must explore new ways to help each other to maintain expertise, not least within the archaeological field.

\section{REFERENCES}

Budgetpropositionen för 20I8. 20I7. Regeringens proposition 20I7/I8:I. Utgiftsområde I7. Kultur, medier, trossamfund och fritid. Stockholm: Regeringen.

Kulturarvspolitik. 2017. Regeringens proposition 20I6/I7:I I6. Stockholm: Riksdagen.

Kulturmiljöförordning (SFS ı988:Iı88). Kulturdepartementet. Utfärdad I988-ı I-IO. Ändring införd t.o.m. SFS 2017:56I.

Kulturmiliöns mangfald. 2013. Regeringens proposition 2012/I3:96. Stockholm: Regeringen. 
Länsmuseernas situation: En konsultrapport. 20I6. Visby: Riksutställningar.

Länsmuseernas och motsvarande museers kulturmiljöarbete: Kartläggning och redovisning av förutsättningarna för samverkan och verksambetsutveckling på regional nivå. 2015. Stockholm: Riksantikvarieämbetet.

Ökadkonkurrenspådetuppdragsarkeologiska området: Vissaändringarikulturminneslagen. 20I I. Stockholm: Kulturdepartementet.

Westerberg, J. O. 20I7. Bevarade kulturmiliöer och utvecklat sambälle:Rapport. Stockholm: Kulturförvaltningen, Stockholms läns landsting.

\section{Internet resource}

Boyle, G., Booth, N. \& Rawden. A. 2016. Collecting Archaeology (England). Report Year I: November 20I6. Society for Museum Archaeology/Historic England. [online] Available at: <http://socmusarch.org.uk/socmusarch/gailmark/wordpress/ wp-content/uploads/20I6/o7/HE-SURVEY-20I6-FINAL.pdf $>$ [Accessed 6 October 2017].

Glasgow Conference Guide 7-9 November 2016. The Museums Association. [online] Available at: <https://view.pagetiger.com/glasgow20r6/guide> [Accessed 20 December 20I7]. 



\title{
WITHOUT MUSEUMS WITH A LONG-TERM PERSPECTIVE, PUBLIC ARCHAEOLOGY IS AT RISK OF BECOMING A DAY-TO-DAY EVENT
}

\author{
Eva Skyllberg \\ Riksantikvarieämbetet \\ Box 5405, 11484 Stockholm, Sweden \\ eva.skyllberg@raa.se
}

Public archaeology within contract archaeology represents a considerable communication effort. This is also the aim of the government expressed in the change of legislation in 2014 when communication came to be comprised by the Historic Environment Act. Communication is done at most of the larger excavations, with guided tours, lectures, information on websites and exhibitions. Sometimes more ambitious communication projects are also undertaken, such as popular science books and other publications.

From a European point of view Sweden is a pioneer in including communication as one of the products covered by the budget paid for by the developer. Many countries are still struggling for contract archaeology to include something more than the basic documentation and to get resources for conservation of artefacts. In other places very good communication is done. In France, for example, thematic and regional overviews for the general public are presented based on the archaeological results.

Contract archaeology constantly produces new source material and interesting results that give new knowledge about the past. But, contract archaeology has difficulties reaching out in society with its results and creating research about relevant subjects. These problems originate 
from the connection to individual projects. There are resources within the project budget for research about the excavated site, but it is more difficult to meet the demand for historic knowledge. What society needs is not research about the individual sites excavated by that contract archaeology, but histories such as: Mälardalen during the Iron Age or The Medieval Town. The results of contract archaeology could be an excellent means to create relevant and useful knowledge but today much of its potential is unexploited. Syntheses are constantly in demand but resources are lacking in the system.

For communication of the results to the general public the picture is the same. Communication takes place about the different sites during the excavation. The communication stops when the excavation is over but the results need to be transferred to continued communication activities. There has to be a base for long-term activities where contacts between different parties can develop. There is a need for comprehensive knowledge building as a basis for communication and a permanency in time and space. This is where the museums have a role that cannot be filled by anyone else.

Museums have a very important role as a link between the archaeologist in contract archaeology or the researcher and the general public. The assignment for the regional museums is not clear in this area but when it comes to archaeology it should be to give the citizens access to new knowledge and recent archaeological results. This can hardly been done without relevant competence in the museums. That the museums consider archaeology to be an important activity and that they have good archaeological competence is necessary if we want to meet the national goals for culture heritage as regards people's participation, education and knowledge. 


\title{
MUSEUMS AND ARCHAEOLOGY IN SWEDEN
}

Some Points on a Widening Gap Based on Personal Experience

\author{
Fredrik Svanberg
}

The Swedish National Maritime Museums Box 27131, 10252 Stockholm, Sweden fredrik.svanberg@maritima.se

\section{THE IDEA OF 'MUSEUM ARCHAEOLOGY' IS PART OF THE PROBLEM}

The very use of the strange concept 'museum archaeology' seems to me to signal a current set of problems in the relations between archaeology and museums in Sweden. The concept seems to indicate that when archaeologists work in museums they are doing a special kind of archaeology, or archaeology under special circumstances, rather than doing museum work. The idea inherent in this concept seems to be that archaeologists should not integrate in museums, learn museum skills and widen their set of competences. They should keep to being straight archaeologists, doing archaeology in its classical fashion, though for the moment being based in museums.

This way of thinking, this narrow idea of the potential roles of archaeologists in museums, seems to me to be the core of current problems. If the only possible relation between archaeologists and museums is a relation in which archaeologists based in museums are doing typical archaeological projects or contract archaeology, that is, if archaeologists do not want to integrate with the full range of typical museum work, then 
how can the consequence of this idea be anything other than a widening gap? The latest developments in the nature of Swedish contract archaeology described in the keynote may be adding to the lack of integration, but these developments are not its core.

\section{MUSEUM WORK IS WIDER THAN TRADITIONAL DISCIPLINES}

My own personal experience of having worked in Swedish contract archaeology for a ten-year period in the I990s and early 2000s, then in different roles in the major Swedish archaeological museum for slightly longer and currently heading a museum unit involving several archaeologists should give me some basis for commenting on current issues.

To begin with, 'Archaeologist' is not a standard position in Swedish museums, where positions related to knowledge production or the keeping of collections are typically titled 'intendent' or 'antikvarie' (both concepts translating as 'curator', in some cases maybe 'keeper'). These titles indicate that museum work is typically wider and different from basic training in disciplines such as archaeology and ethnology, from which most or at least many museum professionals in Sweden were traditionally recruited.

A very small number of Swedish museums are specifically archaeological museums while by far the most museums have a much wider scope, where archaeological collections and exhibitions are just one part. Museum work is typically, for example in the latest government assessment of the museum field, divided into three major blocks: collection management, exhibitions plus pedagogical work, and knowledge production (which includes regular scientific research but also the building up of the specific kind of museum information systems). All three parts have their specific skills, challenges and relate to an international basis of knowledge and research.

\section{ARCHAEOLOGICAL TRAINING DOES NOT PREPARE ARCHAEOLOGISTS FOR MUSEUM WORK}

Basic archaeological education in Swedish universities and university colleges is weak when it comes to preparing archaeologists for museum professionalism. Unlike ethnologists, archaeologists are, very often, strangers to museum systems and the special roles and skills in museums. Though there are certainly exceptions, this is my overall ex- 
perience. Many archaeologists tend to see museums as little more than storage places for finds. In particular, there is a general lack of interest within archaeology for a deeper understanding of different kinds of public interaction.

Ethnologists study museums and museum literature in basic training and quite a few move on to do research within ethnology specifically directed at museum issues. Since the nature of museums and current museum questions are seen as part of the subject, adequately taught, and since ethnologists are therefore easily integrated in museums there is no need for a concept of 'museum ethnology'. Museums and museum work quite simply lie within the sphere of what ethnologists know about and do.

\section{A CHANGE OF ATTITUDES IS NEEDED FOR THE FUTURE}

Museums, on the other hand, and this should also be acknowledged, have done less well in following up on the massive public interest in archaeology. In particular the exploring and interpretative process of archaeology - offering both a tool for investigating the past and a very practical, pedagogical illustration of how history is made-have a strong relevance for museums and could have a greater presence there, involving professional archaeologists of course. Needless to say, museums should also be careful to maintain archaeologically trained staff to keep their competence regarding prehistory and the early parts of history and its material remains, which no other staff can provide.

My principal hopes for the future, however, would be for a general change of attitudes within archaeology. There is need for a deeper understanding and competence among archaeologists regarding museums. This should be established in basic academic training to a much higher degree than is currently the case. The full complexity of museum issues needs to be pulled into the sphere of what archaeologists know about and do, because museums and archaeologists need each other. 



\section{ARCHAEOLOGY IN MUSEUMS IS ESSENTIAL!}

\section{Susanne Thedéen}

Gotland Museum

Strandgatan 14, 62156 Visby, Sweden

susanne.thedeen@gotlandsmuseum.se

Swedish museums now operate within an increasingly professional and complex sphere, expanding way beyond the traditional role of a cultural institution. Our status of Länsmuseum (county museum) means that we cannot envisage any great increase in subsidies from the state or local government, so other sources of revenue such as our contracted assignments, along with admission fees, retail sales from our shop, external projects and sponsorship via strategic partnership are all of great significance to our development of museum activities.

In fact, offering our professional services through contracted assignments is an important income-generating activity for the museum as a whole. A museum is of course fully entitled to opt out of this source and find other means of funding, but Gotland Museum regards commercial activities in general, including contract archaeological excavations, as one of the most important elements of museum operations. This is for two reasons. Firstly, contracted assignments generate earned income which boosts the museum's economy. Secondly, they contribute to the expansion of our knowledge bank. The museum's contracted assignments focus primarily on archaeology and building preservation. But Gotland 
Museum also undertakes and develops revenue-generating activities in other fields, such as exhibitions, education, etc.

Geographically, we mainly operate on Gotland, where contract archaeology has so far encountered no more than moderate competition. Competition from local actors is limited and thresholds for companies from the mainland make it difficult to get established and make any profit out of enterprises on Gotland. The market as such is not very extensive, since major land development projects on Gotland are few. Thus, we have not yet had to face the difficult dilemma experienced by other museums. On the other hand, neither have we attempted to set up operations on the mainland, where our prospects of viability are poor, since thresholds are too high and we are too limited, with specialist knowledge primarily related to Gotlandic conditions.

Contract archaeology is closely linked to economic fluctuations while income varies over time, the cost of maintaining permanent staff is constant. This leads to great economic uncertainty and the fluctuating income needs to be supplemented by and adapted to other sources of income. One feasible approach for museums would be to combine projects for research and furthering knowledge with contract archaeology. In this connection, the new Museum Act is favourable in that it emphasizes that museums should contribute to research and furthering knowledge. Museums should take this very seriously and develop strategies for how we are to comply with them and how we should interpret the content of 'contribute to'.

Contract archaeology is an important feature in Gotland Museum's operations, and it is utilized in our collection management, in our activities with the public at large and not least in our furthering of knowledge. Our archaeologists also work with public service and education, where part of their employment is funded by subsidies from the government-based Cultural Collaboration Model (20II). This ensures that the knowledge gained from contract archaeology is made available to museum visitors through lectures, guided tours and organized walks.

On a national level, where competition is fierce, the situation is quite different. But to begin with, museums do not necessarily have to carry out contract archaeology as a commercial enterprise. It is quite possible to work with different sources of revenue within museum management, but entrepreneurship must be 'a separate entity'. Furthermore, conducting contract archaeology as a commercial enterprise does not necessarily entail loss of knowledge per se. Organization can well be formed so that knowledge is transferred between the commercial enterprise and the museum. The greatest problem lies in the situation whereby a museum abstains from any form of contract archaeology due to harsher compe- 
tition and lack of profit. This situation leads to a need of institutionalized arenas, such as universities or colleges for spreading knowledge. Another conceivable actor would be Länsstyrelserna (the County Administrative Boards).

These new prerequisites place new and different demands both on leadership and on economic know-how within the museum sector. This is one key to success for new museum archaeology. 



\section{THE IMPORTANCE OF RESEARCH FOR COUNTY MUSEUMS}

Joakim Wehlin

Dalarnas museum

Box 22, 79121 Falun, Sweden

joakim.wehlin@dalarnasmuseum.se

The demand for knowledge often goes hand in hand with qualified research work. However, many museums base their work on previously conducted research, since no or very little research work is performed by the museums themselves.

Few Länsmuseer (county museums) today employ archaeologists who are not in part developer-funded. On the contrary, a common situation is that contract archaeology enables many museums to retain their qualified archaeological staff. This is a circumstance that I consider a problem. The focus is on specific assignments, which may indeed include communicative work as well as research. Nevertheless, the areas to be studied are chosen by the market, that is to say, the developer. Lacunas in the research are thus only studied in exceptional cases.

Archaeology is essentially a scientific subject, one of the oldest university disciplines. During a large part of the twentieth century, many of the museums were classified as learned institutions. They were included in the educational system and an unquestionable part of museum work therefore included extensive research work on the subjects represented at the museums. Among the public, Länsmuseerna stood for qualita- 
tive knowledge about the regional cultural history, and an important part of this was archaeology.

These museums used to have a distinct research basis in their work, but today this has generally become rare. It is of vital importance to return to this basis, otherwise the quality of knowledge at the museums tends to become watered down.

\section{THE CRUCIAL ROLE OF LÄNSMUSEER}

In Sweden, there are three general categories of museums. There are state-owned central museums, Länsmuseer and a heterogeneous group of other museums. The latter group covers a wide spectrum including larger national museums and smaller local museums. Central museums and Länsmuseer have specific assignments and responsibilities.

Länsmuseer developed during the early twentieth century as a way of extending state heritage management throughout the country (SOU I922:II-I2 Betänkande med förslag till lag angående kulturminnesvard samt organisation av kulturminnesvarden I922). The state contributed funding and civil servants, who soon found local funding, and the museums grew to become important institutions for knowledge. In the post-war period, the organization of the museums was restructured into trusts. The trustees were municipalities and county councils, often in collaboration with regional heritage societies. During the I970s, Swedish museum organization was transformed. In the new model, the function of Länsmuseer was to act as advisors in the planning work of the municipalities. This work included surveys, providing knowledgeable information, care and restoration, but also performing certain assignments included in the heritage management of the state. This is a responsibility of these museums that is still carried out jointly with Länsstyrelsen (the County Administrative Board). The exact nature of this collaboration varies to a certain extent from region to region (SOU 2015:89 Ny Museipolitik: Betänkande av Museiutredningen 20I4/I5 2015; Prop. 20I6/I7:116 Kulturarvspolitik 2017).

Länsmuseerna carry a tradition that is vital in this context, not least with reference to the local connection. This is a question advocated by Länsmuseernas samarbetsråd (The Collaboration Council of the County Museums) through the slogan Sweden's Largest Museum (Länsmuseernas samarbetsråd n.d.). Central museums are chiefly located in the main cities of Sweden (Stockholm and Gothenburg), while Länsmuseerna act as arenas across the country for management of cultural and social questions. For many Swedes, Länsmuseet of their own 
region is the first that comes to mind, both as a museum and as a source of knowledge. The museum stands for reliability and trustworthiness, providing many with a channel to gain knowledge about the outcome of research, presented in an accessible way.

The trustworthiness of the museums is based on a link to research that was a natural part of the work during the second half of the twentieth century. At Länsmuseerna, there were research councils and formulated research programmes. Dalarna's Museum was a good example; the director of the museum then in office expressed himself as follows: 'A meaningful and socially based cultural policy needs continual research, which adds fuel, new knowledge, new ideas and new values' (translated here, Hofrén 1974). In the case of the museum of Dalarna, the research work was taken over by the county council and was to a greater degree oriented towards the public sector, which most likely also occurred in other parts of the country. This meant that, over the years, questions that were specific for the museums were left behind, which to my mind is a problem.

\section{RESEARCH AT MUSEUMS TODAY}

A few years ago, a survey of research at Swedish museums was conducted (Lihammer 2009). The project provided a concise overview of the research, the researchers and the conditions under which they work. The situation differs among the museums, but there are certain tendencies in common.

For example:

- The knowledge used at the museums is often based on research from the middle of the twentieth century or earlier.

- Research that is conducted today is often based on external projects, often with a weak link to the knowledge requirements of the museum.

- Questions that the museums need to research are not treated by academic research.

- Too few among the staff of the museums have a doctoral degree and their duties do not allow time for research work, or even time to formulate research projects.

- However, the scientific quality of the work and the qualifications of the staff are high. There is also a consensus that research is a necessary part of the work and future of these institutions. 
- The infrastructure of research is poor at the museums. Research work is conducted, but quite often there is a lack of research coordination, research programmes, research councils, scientific reference groups and strategic collaboration.

The situation seems to be turning the right way since the report about research at museums was published. For example, a network named FOMU - research at museums, has been established during the past couple of years. The network acts to support research at museums and thereby also to develop museums as well as the research sector. Many of Länsmuseerna have been assessing their work and organization, not least to be able to meet budgets that are gradually getting tighter. The research basis, however, is still pointed out as an important part of the work. Several of the museums, among others Dalarna's Museum and lately Gotland's Museum, clarify the importance of a research basis when reworking their strategic agenda.

\section{A RESEARCH BASIS IS THE FUTURE}

New assignments have been allocated to the museums. This is, for example, expressed by the government when stating that the cultural heritage should be everybody's concern, that public debate should be broadened and given more depth and that public co-creation and involvement should be encouraged. The main purpose of the museum regulation that came into effect in August 2017 (SFS 2017:563 Museilag 2017) is to 'strengthen the independence of the institutions, and their status as institutions of knowledge' (translated here, Prop. 2016/17:1 16 Kulturarvspolitik 20I7). This requires improved competence and partially a new direction for museum production. The Museum Act $\$ 8$ states that: 'A museum should contribute to research and other accumulation of knowledge, among other ways by maintaining a high standard of competence within its field of knowledge' (translated here, SFS 2017:563 Museilag 2017).

However, a more substantial research basis at museums requires increased collaboration with universities, greater possibilities to apply for funding, with calls for proposals open for all museums (not only state museums), research that is relevant to the work of the museum, a greater number of staff members with doctoral degrees, but there should also be an explicit state requirement for research to be conducted at museums. By participating actively in research, museums can strengthen their scientific perspective and build up their trustworthiness. The scientific 
quality of the generated knowledge will increase. Employing staff with $\mathrm{PhD}$ qualifications opens up for possibilities of applying for research funding and collaborating with other parties involved in research work.

To meet this challenge, it would be interesting, for example, to create a research programme for the museum sector. Such a programme could be specifically oriented towards museum staff for conducting doctoral studies but also for already qualified $\mathrm{PhD}$ staff. This would reinforce the museums' scientific standing, although first and foremost it would strengthen their role as independent institutions in the pursuit of knowledge.

\section{REFERENCES}

Betänkande med förslag till lag angående kulturminnesvård samt organisation av kulturminnesvarden. 1922. Statens offentliga utredningar I922:I I-I2. Stockholm.

Hofrén, E. (Ed.). 1974. Att välja forntid: [lägesrapport]. Falun: Dalarnas museums forskningsråd.

Kulturarvspolitik. 2017. Regeringens proposition 20I6/I7:I I6. Stockholm: Riksdagen.

Lihammer, A. 2009. Forskningen vid svenska ABM-institutioner: En undersökning av aktuella förutsättningar och trender. Stockholm: Nobel Museum.

Museilag. 20I7. Svensk författningssamling 20I7:563. Stockholm: Kulturdepartementet.

Ny Museipolitik: Betänkande av Museiutredningen 20I4/I5. 20I5. Statens offentliga utredningar 2015:89. Stockholm: Wolters Kluwer.

\section{Internet resources}

Länsmuseernas samarbetsråd. n.d. [online] Availible at: <http://www.länsmuseerna. se> [Accessed I8 September 2017].

Sverige museer. n.d. Forskning vid museer (FOMU): Programförklaring. Karlskrona: Sverige museer. [online] Availible at: <http://www.sverigesmuseer.se/wp/wpcontent/uploads/20I5/I I/Programforklaring.pdf> [Accessed I8 September 20I7]. 